NATIONAL LABORATORY

\title{
A Comparison of the 2003 and 2006 International Energy Conservation Codes to Determine the Potential Impact on Residential Building Energy Efficiency
}

April 10, 2007

Prepared by Therese K. Stovall Van D. Baxter

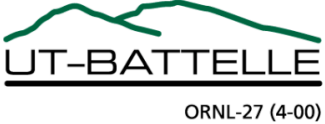




\title{
DOCUMENT AVAILABILITY
}

Reports produced after January 1, 1996, are generally available free via the U.S. Department of Energy (DOE) Information Bridge.

Web site http://www.osti.gov/bridge

Reports produced before January 1, 1996, may be purchased by members of the public from the following source.

\author{
National Technical Information Service \\ 5285 Port Royal Road \\ Springfield, VA 22161 \\ Telephone 703-605-6000 (1-800-553-6847) \\ TDD 703-487-4639 \\ Fax 703-605-6900 \\ E-mail info@ntis.gov \\ Web site http://www.ntis.gov/support/ordernowabout.htm
}

Reports are available to DOE employees, DOE contractors, Energy Technology Data Exchange (ETDE) representatives, and International Nuclear Information System (INIS) representatives from the following source.

Office of Scientific and Technical Information

P.O. Box 62

Oak Ridge, TN 37831

Telephone 865-576-8401

Fax 865-576-5728

E-mail reports@osti.gov

Web site http://www.osti.gov/contact.html

\begin{abstract}
This report was prepared as an account of work sponsored by an agency of the United States Government. Neither the United States Government nor any agency thereof, nor any of their employees, makes any warranty, express or implied, or assumes any legal liability or responsibility for the accuracy, completeness, or usefulness of any information, apparatus, product, or process disclosed, or represents that its use would not infringe privately owned rights. Reference herein to any specific commercial product, process, or service by trade name, trademark, manufacturer, or otherwise, does not necessarily constitute or imply its endorsement, recommendation, or favoring by the United States Government or any agency thereof. The views and opinions of authors expressed herein do not necessarily state or reflect those of the United States Government or any agency thereof.
\end{abstract}


Engineering Science and Technology Division

\title{
A Comparison of the 2003 and 2006 International Energy Conservation Codes to Determine the Potential Impact on Residential Building Energy Efficiency
}

\author{
Therese K. Stovall \\ Van D. Baxter
}

Date Published: April 2007

Prepared by

OAK RIDGE NATIONAL LABORATORY

Oak Ridge, Tennessee 37831-6283

managed by

UT-BATTELLE, LLC

for the

U.S. DEPARTMENT OF ENERGY

under contract DE-AC05-00OR22725 



\section{Contents}

Page

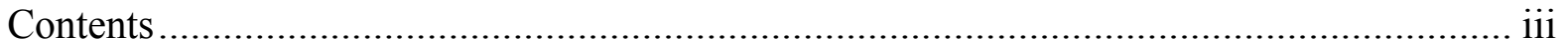

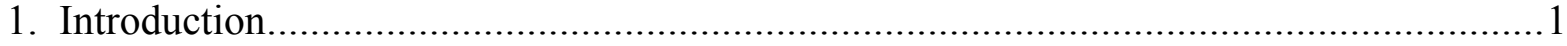

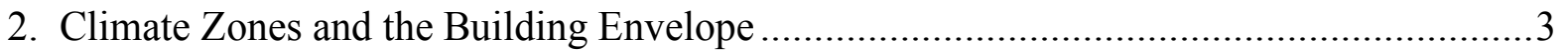

2.1 A Five-State Review..................................................................................... 5

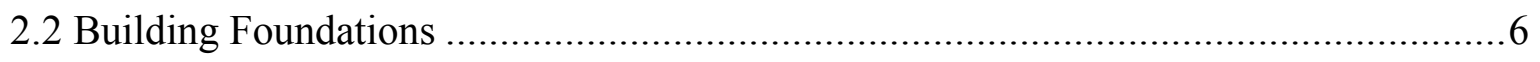

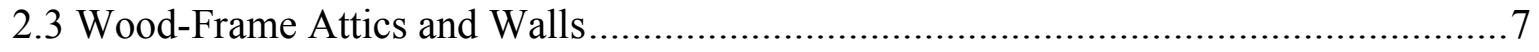

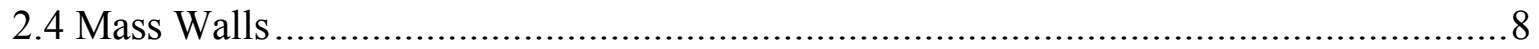

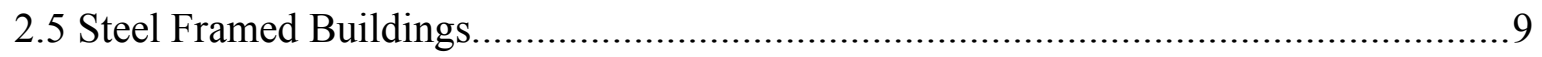

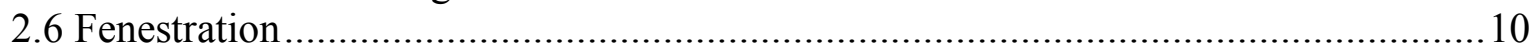

2.7 Total UA Alternative Methods...................................................................... 12

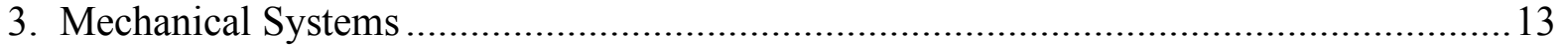

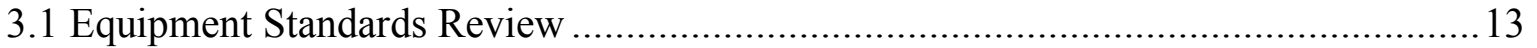

3.2 Heating and Cooling Equipment Sizing .................................................. 15

3.3 Duct and Pipe Insulation Requirements Review ........................................ 15

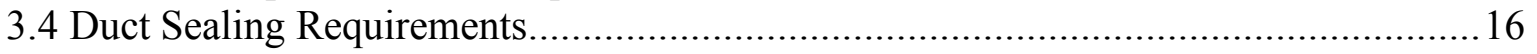

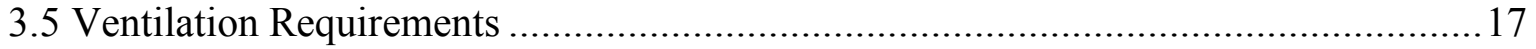

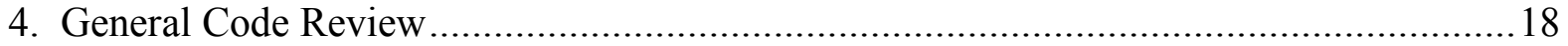

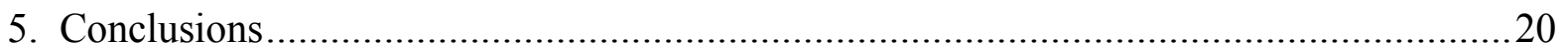

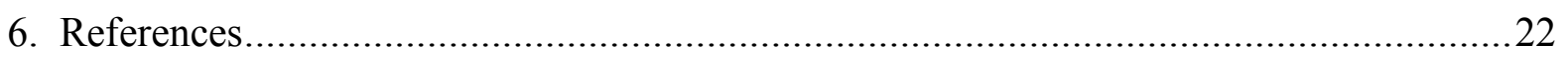

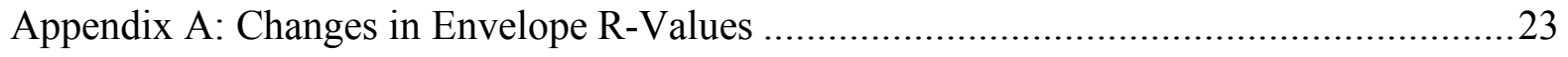

Appendix B: Change in Fenestration Factors .......................................................... 41

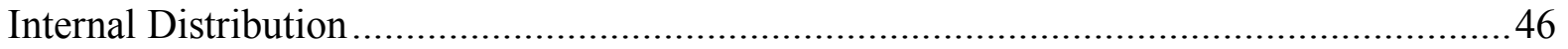

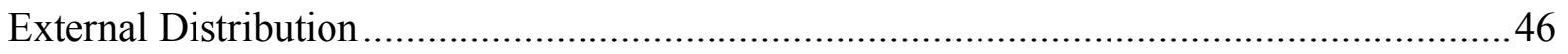




\section{Introduction}

The International Energy Conservation Code (IECC) was updated in 2006. ${ }^{1}$ As required in the Energy Conservation and Production Act of 1992, Title 3, the U. S. Department of Energy (DOE) has a legislative requirement to "determine whether such revision would improve energy efficiency in residential buildings" within 12 months of the latest revision. ${ }^{2}$ This requirement is part of a three-year cycle of regular code updates. To meet this requirement, an independent review was completed using personnel experienced in building science but not involved in the code development process. The scope of this comparison was the material within the 2006 IECC chapters 1 to 4, exclusive of section 4.404. That is, the comparison encompassed residential building requirements except those termed "whole building" or "simulated performance". The comparison was based upon the published IECC documents. No quality assurance reviews of code-development models were made and no new models were developed.

The 2003 version offered four basic approaches:

- Component-based with:

- Maximum assembly U-factors, where the wall assembly includes fenestration, and maximum fenestration solar heat gain coefficient (SHGC) (502.2.1); or

- Acceptable Practice (502.2.3) - must meet 502.2.1 but provides extensive tables to identify the U-factors for common assemblies;

- Total UA Alternative(502.2.2): must meet equivalent building from 502.2.1;

- Prescriptive:

○ Minimum insulation R-values, maximum fenestration U-factors, and maximum fenestration SHGC for buildings as a function of percent glazing and heating degree days (502.2.4);

○ Simplified (Chapter 6) - same approach for buildings with minimal glazing;

- Simulated Performance Alternative (Chapter 4): not evaluated.

The 2006 IECC has been considerably streamlined compared to the 2003 version, and includes a major re-structuring. The 2006 version offers three options:

- General (Prescriptive) - component-based with:

○ Minimum insulation R-values, maximum fenestration U-factors, and maximum fenestration SHGC (402.1.1); or

- Equivalent maximum assembly U-factors, where the walls and fenestration are specified separately, and maximum fenestration SHGC(402.1.3);

- Total UA Alternative(402.1.4): must meet equivalent building from 402.1.3;

- Simulated Performance Alternative (404): not evaluated.

It has been stated that, "The 2006 IECC was designed primarily to improve the code's usability and enforceability - energy efficiency was intentionally held nearly constant." 3 This goal is evident in the new organization used for the 2006 IECC. The reorganization has vastly improved the code's presentation, making it much simpler to read and understand. This improvement may increase the adoption of the code by local code bodies and may increase the compliance levels due to enhanced understanding. The reorganization also makes a direct comparison of the two documents somewhat challenging. The envelope assembly U-factors are not comparable because the 2003 version includes windows within the assembly and the 2006 does not. The best 
basis for comparison is, therefore, the prescriptive R-value options. Because the $2006 \mathrm{R}$-values are not a function of the percent glazing, they were compared to the range of R-values from the 2003 edition. Section 502.2.4 in the 2003 IECC was chosen as the basis for comparison to the 2006 General Prescriptive (402.1.1) approach because it includes a broader range of window fractions than the 2003 Simplified Prescriptive (Chapter 6) approach.

The reorganization includes three major changes that were considered within this review. First, 17 climate zones were collapsed into eight. Second, the impact of the amount of glazing was removed from the prescriptive procedures. Third, most of the details regarding mechanical systems and water heating were removed from the document and replaced with a reliance on related standards and/or Federal minimum efficiency requirements. In addition to these major changes, a general review was made to look for other changes in the code that might have an impact on building energy efficiency. 


\section{Climate Zones and the Building Envelope}

In both the 2003 and 2006 IECC, climate zones are used to assign minimum R-values and maximum U-factors for the building envelope. In 2003, the climate zones were defined solely by heating degree days (HDD); 17 zones based on increments of 500 HDD were used. In 2006, eight climate zones are based on a combination of cooling degree days (CDD), HDD, and relative humidity, with a special designation for a marine region on the US west coast. Section 502.2.4 in the 2003 IECC specified the required R-value for the envelope components for each zone, as does Section 402.1.1 in the 2006 IECC. A broad comparison of these climate-zone/Rvalues and $\mathrm{U}$-factors is presented in Appendices $\mathrm{A}$ and $\mathrm{B}{ }^{\mathrm{a}}$

This overall comparison shows a mixture of situations where R-values and U-factors are increased, stay the same, or decreased, depending upon the building location, amount of glazing, and foundation type. Therefore, the determination as to "whether such revision would improve energy efficiency in residential buildings" will depend upon the scale of the review. Such a determination would be relatively straightforward on a local scale, where the dominant building practices and climate are well defined. On a national scale, a quantitative analysis would require detailed information about both location-specific building practices and location-specific new building volume in order to produce a weighted estimate of the aggregate impact on residential energy consumption. Such data resources were not available within the time constraints of this review. Therefore, a more qualitative assessment is presented here.

While the appendices provide specific comparisons for combinations of climate zone and percent glazing, they don't contain data regarding the local building practices. For example, crawl space insulation is not likely to be an important factor in Minneapolis, just as basement insulation is not likely to be an important factor in Miami. The relative importance of increases and decreases in building envelope insulation requirements is also influenced by the population distribution. For example, changes in requirements for Chicago will have a bigger impact on national energy consumption than changes in Sturgis, SD. Note that the tables in Appendices A and B list the states included in each climate zone, so the reader may get some idea of the regional impact of the changes.

Another way to get a qualitative grip on the changes between the 2003 and 2006 IECC is to consider the ranges of R-values and U-factors specified. In the 2003 IECC, the required Rvalues were a function of the amount of glazing, as shown in Table 1. In theory, this allowed reduced glazing U-values and greater envelope R-values to compensate for the greater building loads associated with greater amounts of glazing, as shown in Figure 1. In practice however, this added complexity also introduced interesting variations in the required insulation levels, as exhibited in Table 1 for floor insulation. For some cases, such as crawl space insulation, 2006

\footnotetext{
${ }^{a}$ The tables in Appendix A are based upon an extensive unpublished analysis prepared previously by ICF, International. In both appendices, the changes between the 2003 and 2006 IECC documents are highlighted with a blue shaded area. For both the insulation R-values and the glazing U-factors, changes in the 2006 IECC that improve the thermal resistance of the building envelope are shown in black. Those changes that decrease the performance of the building envelope shell are shown in red and enclosed in parentheses.
} 
IECC reductions in required R-values are somewhat offset by improved installation specifications. These cases are discussed further later in this section.

Table 1 Graphical Summary of Prescriptive R-Value Ranges in 2003 IECC and 2006 IECC

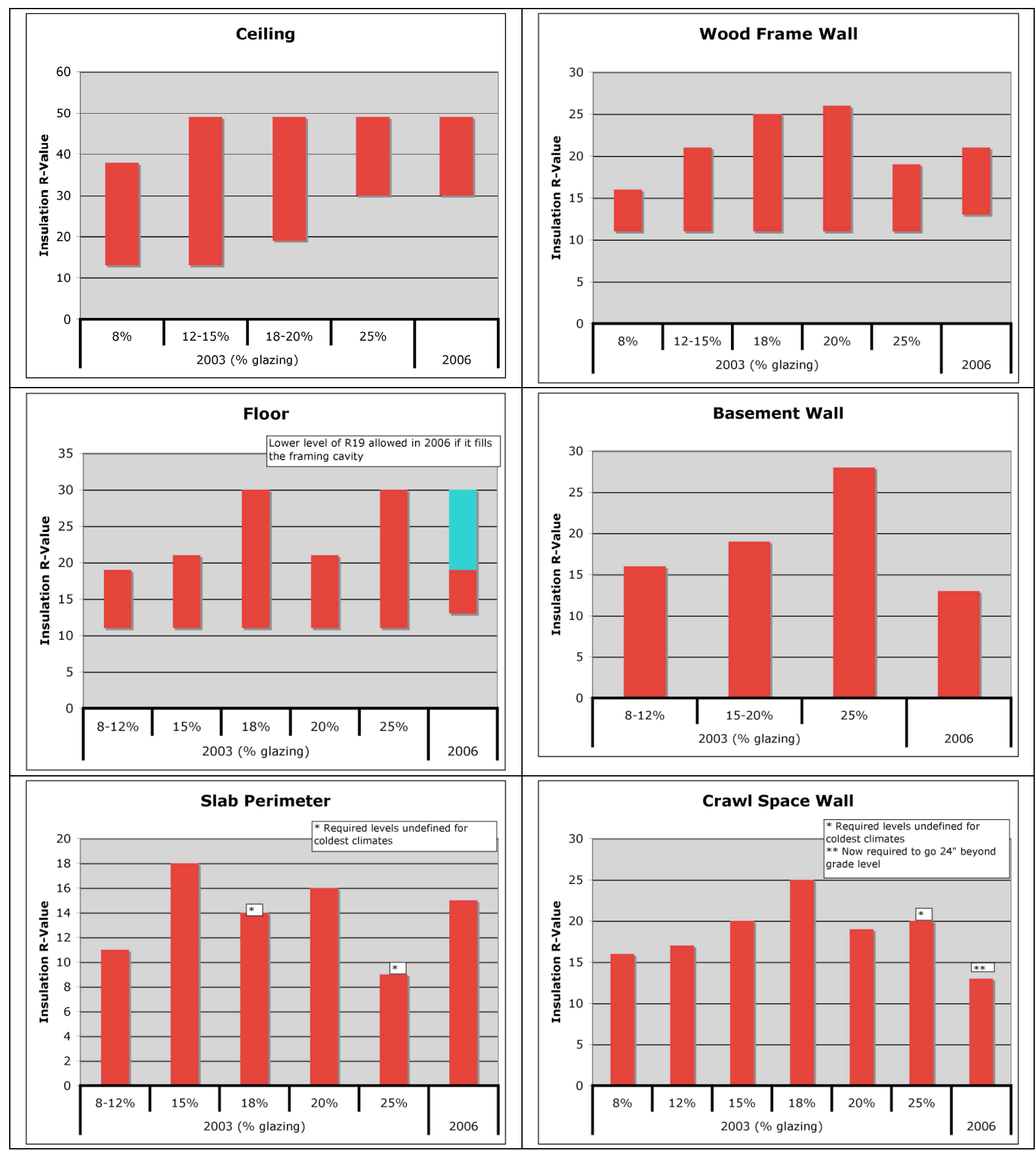


Figure 1 Range of Glazing U-Factors

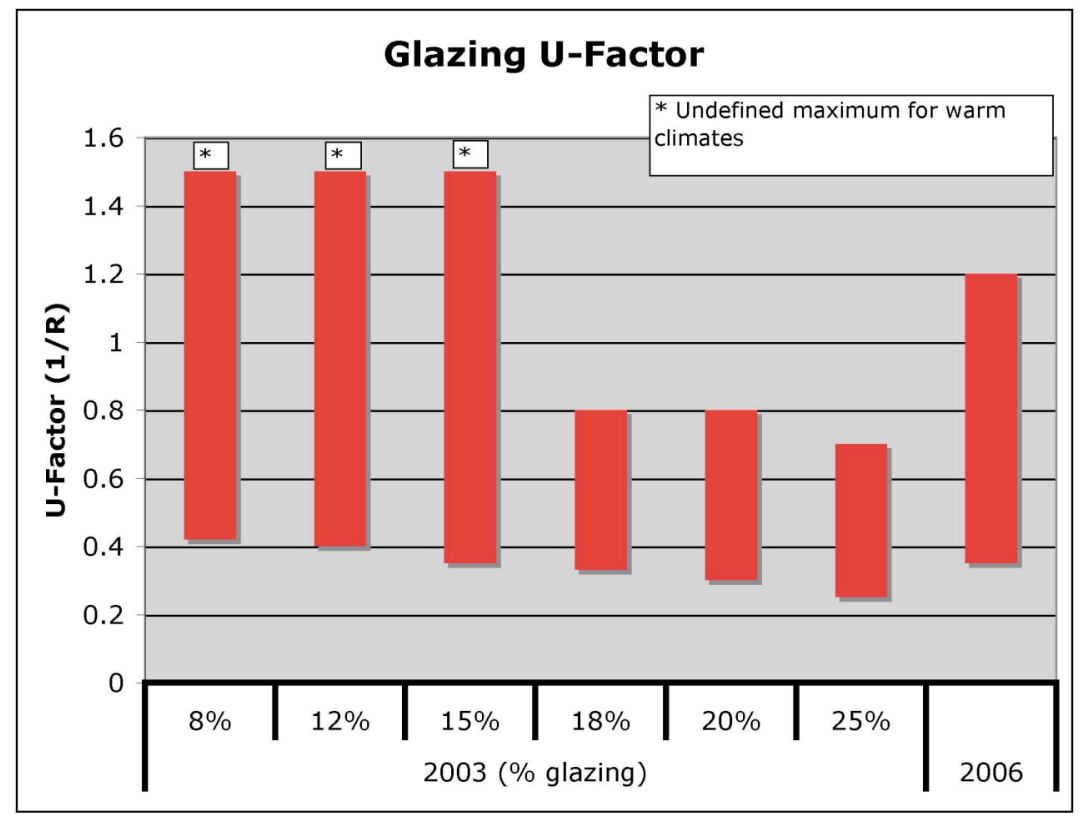

\subsection{A Five-State Review}

To help focus this discussion, the impact of the IECC changes in the states of California, Florida, Michigan, New York, and Texas will be used as examples. These five states cover all the 2006 IECC climate zones represented in Chapter 4, Section 402, and represent over 35\% of the U.S. population.

The southern tip of Florida is in Zone 1 and the remainder of the state is in Zone 2. In the 2006 IECC, the ceiling, wall, floor, basement wall, and slab perimeter insulation R-values have remained the same or slightly increased throughout this area, compared to the 2003 IECC. Crawl space wall insulation was required in a part of the state in the 2003 IECC, but is not required by the 2006 IECC. Both the 2003 and 2006 IECC require a maximum SHGC of 0.4 for the entire state. The glazing U-factors are more stringent in the 2006 IECC for buildings with smaller glazing fractions, and less stringent for buildings with larger glazing fractions. Considering all these changes, the building envelope requirements for Florida for the 2003 and 2006 IECC versions are approximately equivalent.

Most of Texas is in Zones 2 and 3, with a small portion in Zone 4. For the large fraction of the state located in Zone 3, the ceiling insulation requirement has been reduced from R-38 to R-30 in the 2006 IECC for any building with more than $15 \%$ window area. Wall and floor insulation levels are approximately the same across the state in the 2003 and 2006 IECC. Basement and crawlspace wall R-values are less in the 2006 IECC than in the 2003 IECC for most of the state. The unheated slab perimeters receive less insulation, but the heated slabs receive approximately the same or more insulation under the 2006 IECC. Parts of Texas with higher cooling loads are now subject to a maximum SHGC in 2006 where none was required in 2003. The maximum glazing U-factors are significantly less stringent in the 2006 IECC than they were in 2003 for all 
but the coldest portions of the state. Considering all these changes, the building envelope requirements for the 2006 IECC for Texas represent a decrease in stringency (toward greater energy use) compared to the requirements in the 2003 IECC.

California stretches from Zone 2 to Zone 6. Most of the ceiling, wall, and floor insulation Rvalues are unchanged, although the largest and most heavily-populated portion of the state, located in Zone 3, will see a decrease in ceiling insulation requirements from R-38 to R-30 for any building with more than $15 \%$ window area. For most of the state, the basement and crawl space wall insulation R-value requirements are less in the 2006 IECC than in the 2003 IECC. On the other hand, slab perimeter insulation was generally increased for heated slabs and stayed the same or increased for unheated slabs. A very small part of California with higher cooling loads is now subject to a maximum SHGC in 2006 where none was required in 2003. Outside of Zones 2 and 3 , the changes to window glazing U-factors are very small, although the requirements for skylights are less stringent in the 2006 IECC. In Zones 2 and 3, the changes in window U-factors are more significant, but are also mixed, with some situations changing to higher U-factors (e.g., Los Angeles) and some to lower (e.g., San Francisco). Considering all these changes, it appears that the building envelope requirements for the 2006 IECC for California represent a decrease in stringency (toward greater energy use) compared to the requirements in the 2003 IECC.

New York covers Zones 4, 5, and 6. The ceiling insulation requirements are unchanged except for a portion of the state in Zone 5 where the requirement has been reduced from R-49 to R-38. The wall insulation requirements are less in 2006 than in 2003 across much of the state. The floor insulation level has been increased, unless the builder opts to reduce the floor insulation to the level needed to fill the space between the framing, as allowed in the 2006 IECC. Basement wall insulation has increased while crawl space wall insulation has decreased. Slab perimeter insulation is a mixture of more and less stringent requirements in the 2006 IECC compared to the 2003 IECC. Window glazing U-factors are less stringent in 2006 for any building with more than $15 \%$ window area. The skylight U-factors are less stringent in the 2006 IECC. Considering all these changes it appears that the building envelope requirements for New York for the 2006 IECC are less stringent than in the 2003 IECC.

Michigan covers Zones 5, 6, and 7. For ceilings, walls, and floors, the results for Michigan are similar to New York, except that a greater part of the state is subject to reduced wall insulation $\mathrm{R}$-values in the 2006 IECC. The basement insulation requirements are about the same or less in 2006 and the crawl space requirements are also reduced relative to 2003 . The slab perimeter insulation tends to be less in either R-value or depth for both heated and unheated slabs. Window glazing U-factors are approximately the same, although less stringent in 2006 for the colder portion of the state with greater amounts of glazing. The skylight U-factors are less stringent in the 2006 IECC. Considering all these changes it appears that the building envelope requirements for Michigan for the 2006 IECC are less stringent than in the 2003 IECC.

\subsection{Building Foundations}

A quick examination of Table 1 shows that the maximum insulation R-values for floor, basement wall, slab perimeter, and crawl-space wall are all lower in the 2006 IECC than in the 2003 IECC. An examination of the blue-shaded portions of Tables A.1 to A.3 in Appendix A, however, shows that there are many locations where the R-values for foundation insulation have increased. 
For example, the minimum floor insulation has increased from R-11 to R-13, as shown in Tables A.1.1 through A.1.4. And there are other factors, discussed here, that may increase or decrease the stringency of the 2006 IECC compared to the 2003 IECC.

In Section 502.2.4.8 of the 2003 IECC, floors over open outdoor spaces are required to use the greater levels of insulation specified for ceilings. This requirement was dropped from Section 402.2.5 in the 2006 IECC. Also, footnote " $\mathrm{f}$ " to Table 402.1.1 in the 2006 IECC allows the use of less insulation so long as it fills the framing cavity and is at least R-19, so that R-30 is never really required even though it is shown as a requirement in the table. On the other hand, the 2006 IECC requires that the insulation be in permanent contact with underside of the floor so the installation may be of higher quality. Compared to the requirements in the 2003 IECC, this represents a decrease in stringency (toward greater energy use) for the colder climate zones.

Section 402.2.6 of the 2006 IECC requires basement wall insulation for unconditioned basements if the floor above is not insulated. Compared to the requirements in the 2003 IECC, (Section 502.2.4.9) this represents an increase in stringency (toward less energy use).

Section 402.2.8 in the 2006 IECC has improved the crawl space wall insulation with a new requirement to go 24 inches below grade. Improvements with an indirect impact on energy efficiency include a new requirement for a continuous vapor retarder and crawl space wall insulation is now presented as a more explicit alternative to floor insulation. Counterbalancing these improvements is a general reduction in the required R-value. Compared to the requirements in the 2003 IECC (Section 502.2.4.12), the net result of these changes will vary from more to less stringent, depending upon the relative magnitude of these two effects.

Section 402.2.7 in the 2006 IECC has improved the description of slab perimeter insulation installation and has increased the amount of insulation used when the slab is heated. For most locations, the R-value has been increased. However, in the Southern areas covered by Zone 3, where slab construction is common, and in the far north in Zones 7 and 8, the 2006 IECC requires less insulation. Compared to the requirements in the 2003 IECC, the net result of these changes will vary from more to less stringent, depending upon the region.

The forgoing discussion has been for detached one- and two-family dwellings. For R-2, R-4, or townhouse residential buildings, the 2003 IECC gave separate values in Tables 502.2.4(7), (8), and (9). The 2006 IECC does not distinguish between these small multi-unit buildings and the detached one- and two-family dwellings. The prescriptive R-values for floor insulation for these buildings have been increased or left the same for almost all climate zone-window area combinations in the 2006 IECC relative to the 2003 IECC, as shown in Appendix A, Table A.4. Furthermore, there are very few locations, shown in Tables A.4.2 and A.4.3, where the 2006 IECC option to limit the floor insulation to R-19 if it fills the cavity would cause a decrease relative to the 2003 IECC. Compared to the requirements in the 2003 IECC, this represents an increase in stringency for almost all small multi-unit buildings.

\subsection{Wood-Frame Attics and Walls}

The 2003 IECC allowed ceiling R-values as low as R-13 for buildings with very low amounts of windows or in climates with very low HDD. The 2006 IECC has a minimum ceiling R-value of 
R-30. This represents an increase in stringency for many buildings located in Hawaii, a number of U.S. island territories, and the southernmost portions of Florida, Texas, and California.

Both the 2003 and the 2006 IECC recognize that common attic construction practices will not allow the installation of as much insulation near the eaves as in the center, and both allow the same decrease in R-value in this region. The 2003 IECC made no other allowance for reduced ceiling insulation, but the 2006 IECC, Section 402.2.2, explicitly allows a reduction of ceiling insulation to R-30 for up to $500 \mathrm{ft}^{2}$ of ceiling area. Compared to the requirements in the 2003 IECC, this represents a decrease in stringency for most climate zones.

An examination of Tables A.1.2 and A.1.4 shows that the ceiling insulation requirement has been reduced from R-38 to R-30 for much of the new Zone 3, and from R-49 to R-38 for much of the new Zone 5. Compared to the requirements in the 2003 IECC, this represents a decrease in stringency for these two heavily-populated climate zones.

As shown in Tables 1 and A.1.1, the 2003 IECC allowed R-11 wall insulation for buildings with very low amounts of windows or in climates with less than about 2500 HDD. The 2006 IECC has a minimum wall R-value of R-13. This represents an increase in stringency for many buildings located in Hawaii, a number of U.S. island territories, and the southernmost portions of Florida, Texas, and California.

As shown in Tables 1 and A.1.2 to A.1.4, the 2003 IECC required R-19 (or more) wall insulation for buildings with greater amounts of windows in moderate and colder climates. The 2006 IECC presents a wall R-value of R-13 for moderate climates and only reaches R-21 for the coldest climate zone. Therefore, there will be a large number of residential buildings where the wall insulation requirements of the 2003 IECC were greater than those shown in the 2006 IECC. The levels required by the 2003 IECC represented a continuum that would usually require a combination of cavity and sheathing insulation, whereas the 2006 IECC requirements can usually be satisfied by cavity insulation alone. Compared to the 2003 IECC, this represents a decrease in stringency for many buildings located in Zones 4 through 8.

The forgoing discussion has been for detached one- and two-family dwellings. For R-2, R-4, or townhouse residential buildings, the 2003 IECC gave separate values in Tables 502.2.4(7), (8), and (9). The 2006 IECC does not distinguish between these multi-unit buildings and the detached one- and two-family dwellings. The prescriptive R-values for ceilings and walls in these buildings have been increased, many substantially, or left the same for almost all climate zone-window area combinations in the 2006 IECC relative to the 2003 IECC, as shown in Appendix A, Table A.4. This represents an increase in stringency for almost all small multi-unit buildings.

\subsection{Mass Walls}

Section 402.2 .3 in the 2006 IECC specifies that at least $50 \%$ of the insulation must meet the placement requirement for the reduced insulation levels allowed for massive walls. Furthermore, the mass-wall R-values, as defined by comparison to wood-frame wall R-values, have shifted so that less insulation is required in warm climates and more insulation is required in cold climates, as shown in Table 2 and Figure 2. Compared to the requirements in the 2003 IECC (Section 
502.2.4.17), this may represent a decrease in stringency (toward greater energy use) because there was no previous allowance for walls that only partially met the insulation placement definition.

Table 2 Massive Wall Insulation Comparison

\begin{tabular}{|c|c|c|}
\hline Wood frame R-value & $\mathbf{2 0 0 3}$ & $\mathbf{2 0 0 6}$ \\
\hline \multicolumn{3}{|c|}{ Exterior or integral insulation placement } \\
\hline R-13 & R-6 to R-11 & R-3 to R-5 \\
\hline R-19 & R-8 to R-15 & R-13 to R-15 \\
\hline R-21 & R-8 to R-16 & na \\
\hline R-26 & R-9 to R-18 & R-19 \\
\hline \multicolumn{3}{|c|}{ Interior insulation placement } \\
\hline R-13 & R-11 to R-14 & R-13 (R-4 to R-8 in Climate Zones 1-3) \\
\hline R-19 & R-16 to R-20 & R-21 \\
\hline R-21 & R-17 to R-21 & na \\
\hline R-26 & R-21 to R-23 &
\end{tabular}

Figure 2 Mass Wall Insulation Ranges

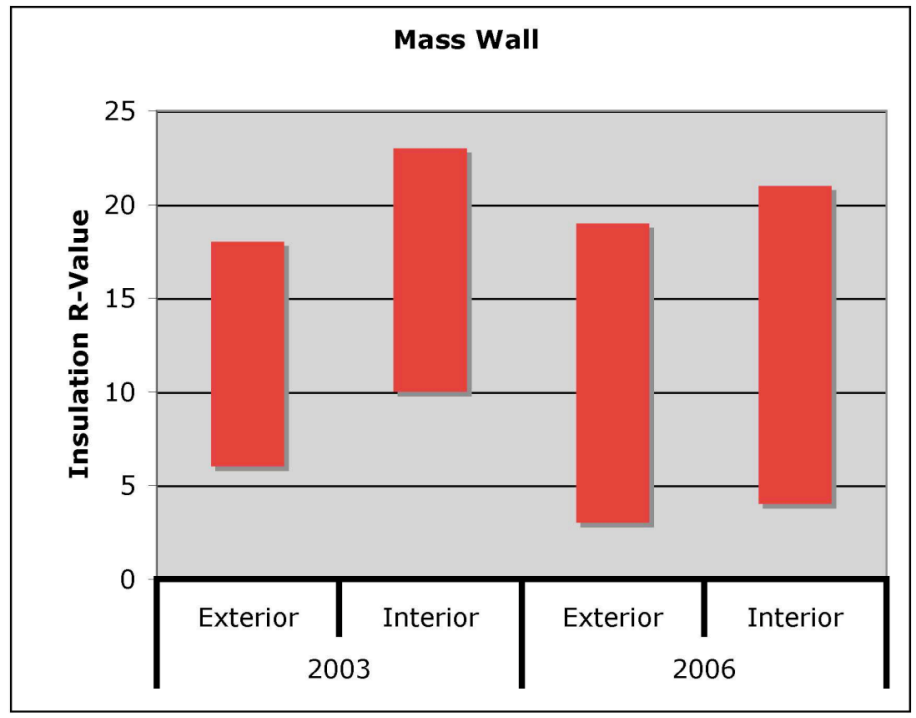

\subsection{Steel Framed Buildings}

Section 402.2.4 of the 2006 IECC and Sections 502.2.4.16, 502.2.4.18, and 502.2.4.19 of the 2003 IECC specify R-values for steel frame walls, ceilings, and floors. Both the 2003 and the 2006 IECC base the insulation requirements on an equivalent to the wood frame R-value insulation requirements. For walls, there has been little change, except for an increase in stringency where R-11 has been replaced by R-13.

For steel truss ceilings, two options have been added and one option has been decreased in the 
2006 IECC relative to the 2003 IECC. R-26/5 has been added as an equivalent to R-30 woodframe ceiling insulation. The 2003 IECC defined R-38/5 for a steel truss ceiling as an equivalent to R-38 in a wood frame ceiling; in 2006, the equivalent for R-38 has been reduced to R-38/3 and R-38/5 is now listed as an equivalent to R-49 in a wood frame ceiling. The 2006 IECC also specifies that any insulation over the level of a ceiling truss must cover the framing.

For a steel joist ceiling or floor, the 2003 IECC used a set of equivalent U-factor tables that were confusing. This element has been simplified in the 2006 IECC by a reference to the same straight-forward U-factor table used for wood framing, with the explicit requirement that a serial/parallel path approach be used.

See Table 3 for a summary comparison of the 2003 and 2006 IECC requirements for steelframed buildings. Compared to the requirements in the 2003 IECC, the 2006 IECC shows a small amount of increased stringency for walls and decreased stringency for ceilings, but the most significant changes will be those associated with the corresponding $R$-value changes for wood-framed buildings.

Table 3 Steel Frame Insulation Comparison

\begin{tabular}{|c|c|c|}
\hline $\begin{array}{c}\text { Wood frame R-value } \\
\text { requirement }\end{array}$ & $\mathbf{2 0 0 3}$ & Steel-frame equivalent R-value* \\
\hline & Steel Framed Walls \\
\hline R-13 & R-11/5, R-15/4, R-21/3 & R-13/5, R-15/4, R-21/3 \\
\hline R-19 & R-11/10, R-13/9, R-19/8, R-25/7 & Same but no R11/10 \\
\hline R-21 & R-13/10, R-19/9, R-25/8 & Same \\
\hline \multicolumn{3}{|c|}{ Steel Truss Ceilings } \\
\hline R-30 & R-38, R-30/3 & Same plus R-26/5 \\
\hline R-38 & R-49, R-38/5 & R-38/5 \\
\hline R-49 & NA & R-38 or R-49, U 0.035 \\
\hline \multicolumn{3}{|c|}{ Steel Joist Ceilings } \\
\hline R-30 & U 0.0355 R-49, U 0.030 \\
\hline R-38 & U 0.0285 & R-19 or R-19/6, U 0.064 \\
\hline R-13 & Steel Joist Floors & R-19/6 or R-19/12, U 0.047 \\
\hline R-19 & U 0.0652 0.0477 &
\end{tabular}

\subsection{Fenestration}

Section 102.1.3 in the 2006 IECC defines the default U-factor and SHGC for unlabeled fenestration products. Categories have been combined and simplified, as shown in Table 4. Door U-factors are more conservative and no longer consider the use of storm doors. For metal windows without a thermal break, the 2006 values are approximately equal to the midpoint of the values from section 102.5.2 of the 2003 IECC. For metal with thermal break and nonmetal windows, the changes are negligible or slightly conservative. Based on the foregoing, the default fenestration U-factors of the 2003 and 2006 versions of the IECC are approximately equivalent.

${ }^{\mathrm{b}}$ Where R-26/5 indicates R-26 cavity insulation plus R-5 continuous insulation. 
As was discussed in the five-state review, and as shown in Appendix B, the maximum U-factor requirement for windows for all buildings with more than $15 \%$ glazed wall area have increased. The maximum U-factor for most skylights has also increased. The maximum door U-factor has increased from 0.35 to 1.2. Compared to the requirements in the 2003 IECC, this represents a decrease in stringency (toward greater energy use).

The comparison for small multi-unit dwellings is very different. The maximum U-factors for these buildings, outlined in the 2003 IECC Tables 50.2.2.4(7) to (9), are significantly greater than those defined in the 2006 IECC in Table 402.1.1 for Zones 4-8, that is, for most of the country. Compared to the requirements in the 2003 IECC, this represents an increase in stringency for small multi-unit buildings.

The maximum SHGC for hot climates has stayed the same, but now applies to a broader geographic region because the applicable climate zones have been expanded due to an explicit consideration of cooling loads. Compared to the requirements in the 2003 IECC, this represents an increase in stringency (toward less energy use).

\section{Table 4 Fenestration Default U-Factor Comparison}

\begin{tabular}{|c|c|c|c|c|}
\hline Fenestration Product & & & 2003 & 2006 \\
\hline \multirow{6}{*}{ Metal without thermal break, U-factors } & Window & Single pane & 1.1 to 1.4 & 1.2 \\
\hline & & Double pane & 0.7 to 0.9 & 0.8 \\
\hline & Skylight & Single pane & 2.0 & 2.0 \\
\hline & & Double pane & 1.3 & 1.3 \\
\hline & Garden & Single pane & 2.6 & - \\
\hline & & Double pane & 1.8 & - \\
\hline \multirow{4}{*}{ Metal with thermal break, U-factors } & Window & Single pane & 1.1 to 1.3 & 1.1 \\
\hline & & Double pane & 0.63 to 0.7 & 0.65 \\
\hline & Skylight & Single pane & 1.9 & 1.9 \\
\hline & & Double pane & 1.1 & 1.1 \\
\hline \multirow{6}{*}{ Nonmetal or metal clad, U-factors } & Window & Single pane & 0.9 to 1.0 & 0.95 \\
\hline & & Double pane & 0.55 to 1.6 & 0.55 \\
\hline & Skylight & Single pane & 1.5 to 1.8 & 1.75 \\
\hline & & Double pane & 0.8 to 1.1 & 1.05 \\
\hline & Garden & Single pane & 2.3 & - \\
\hline & & Double pane & 1.6 & - \\
\hline Glazed block, U-factor & & & 0.6 & 0.6 \\
\hline \multirow{2}{*}{ Metal door, U-factor } & & Uninsulated & 0.6 & 1.2 \\
\hline & & Insulated & 0.35 & 0.6 \\
\hline Wood door, U-factor & & & 0.3 to 0.4 & 0.5 \\
\hline Special insulated door, U-factor & & & - & 0.35 \\
\hline \multirow{5}{*}{ SHGC } & Clear & Single pane & 0.6 to 0.8 & 0.8 \\
\hline & & Double pane & 0.6 to 0.7 & 0.7 \\
\hline & Tinted & Single pane & 0.5 to 0.7 & 0.7 \\
\hline & & Double pane & 0.4 to 0.6 & 0.6 \\
\hline & Glazed block & & - & 0.6 \\
\hline
\end{tabular}




\subsection{Total UA Alternative Methods}

The total UA Alternative Methods in the 2006 and 2003 IECCs are essentially the same. The 2006 IECC is somewhat more stringent in that it:

- Explicitly includes the thermal bridging effects of framing materials; and

- Adds the Maximum SHGC requirement.

This analysis did not verify internal consistency between the assembly U-values and the prescriptive insulation R-values. If each code is internally consistent, then the comparison of the 2006 and 2003 IECC Total UA Alternative Methods should produce the same results as the comparison of the prescriptive approaches. 


\section{Mechanical Systems}

Sections 503, 504, and 505 in the 2003 IECC include extensive specifications over about five pages for single-dwelling mechanical and electrical systems characteristics, and refer to the commercial building requirements for larger systems that would serve multiple dwellings within a single residential building, such as a small apartment building or a dormitory. (Low-rise multiple-occupant buildings, designated R-2, are included within the residential building scope in both the 2003 and 2006 IECC.) The 2006 IECC includes less than half a page of mechanical system requirements, and refers to other standards only for system installation, duct sealing, and equipment sizing. The mechanical system efficiency is of obvious importance in this comparison of the 2003 and 2006 IECC to "determine whether such revision would improve energy efficiency in residential buildings", especially if improvements in mechanical systems are available to offset possible reductions in the building envelope efficiency.

A number of specific mechanical system energy conservation topics were addressed in the 2003 IECC, but are not included in the 2006 IECC for residential buildings. The 2003 IECC, sections 503.3.6 and 503.3.7, placed a cap on transport energy (fan and pump energy) and required system balancing. This requirement would most likely effect larger buildings in the R-2 class. Low flow showerheads were required in section 504.6.1 of the 2003 IECC. Swimming pool energy conservation measures are listed in section 5.4.3 of the 2003 IECC. There are no parallel requirements in 2006. This represents a decrease in stringency (toward greater energy use).

Some systems, including new single-dwelling HVAC units and water heaters, are covered by other federal standards. For information purposes, these other standards have been examined during this review, even though they are not referenced in the 2006 IECC and therefore cannot be considered to have increased or decreased the stringency relative to the 2003 IECC.

\subsection{Equipment Standards Review}

The 2006 IECC, Section 403, includes no requirements for mechanical systems for residences. For information purposes, Table 5 provides a review of federally mandated minimum efficiency levels for heating, cooling, and water heating equipment and an indication of where equipment efficiency stringency has increased (higher efficiency is required) since publication of the 2003 IECC. Note that these changes have occurred in parallel with the IECC changes, but none of these changes are attributable to the 2006 IECC, nor can they be considered as a factor in determining whether the 2006 IECC is more or less stringent than the 2003 IECC. 
Table 5 Comparison of 2006 Federal Standards for Residential Equipment to the 2003 IECC Mechanical Equipment Requirements

\begin{tabular}{|c|c|c|c|c|}
\hline $\begin{array}{l}\text { Equipment } \\
\text { category }\end{array}$ & $\begin{array}{l}\text { Sub- } \\
\text { category }\end{array}$ & $\begin{array}{l}\text { IECC } 2003 \\
\text { efficiency } \\
\text { requirements }\end{array}$ & $\begin{array}{l}\text { Latest } \\
\text { minimum } \\
\text { Federal } \\
\text { requirements }\end{array}$ & Comments \\
\hline \multirow{2}{*}{$\begin{array}{l}\text { Air-cooled heat } \\
\text { pumps, heating } \\
\text { mode; }<65,000 \\
\text { Btu/h cooling } \\
\text { capacity }\end{array}$} & $\begin{array}{l}\text { Split } \\
\text { systems }\end{array}$ & $\begin{array}{l}\text { 6.8 HSPF } \\
\text { (Table 503.2) }\end{array}$ & 7.7 HSPF & \multirow{2}{*}{$\begin{array}{l}\text { Effective date }-1 / 23 / 2006^{4} \\
\text { HSPF as determined per } \\
\text { ARI } 210 / 240\end{array}$} \\
\hline & $\begin{array}{l}\text { Single } \\
\text { package }\end{array}$ & $\begin{array}{l}\text { 6.6 HSPF } \\
\text { (Table 503.2) }\end{array}$ & 7.7 HSPF & \\
\hline \multirow{2}{*}{$\begin{array}{l}\text { Air-cooled air } \\
\text { conditioners and } \\
\text { heat pumps, cooling } \\
\text { mode; }<65,000 \\
\text { Btu/h cooling } \\
\text { capacity }\end{array}$} & $\begin{array}{l}\text { Split } \\
\text { systems }\end{array}$ & $\begin{array}{l}\text { 10.0 SEER } \\
\text { (Table 503.2) }\end{array}$ & 13.0 SEER & \multirow{2}{*}{$\begin{array}{l}\text { Effective date }-1 / 23 / 2006^{4} \\
\text { SEER as determined per } \\
\text { ARI } 210 / 240\end{array}$} \\
\hline & $\begin{array}{l}\text { Single } \\
\text { package }\end{array}$ & $\begin{array}{l}\text { 9.7 SEER } \\
(\text { Table 503.2) }\end{array}$ & 13.0 SEER & \\
\hline $\begin{array}{l}\text { Gas-fired or oil-fired } \\
\text { furnace; }<225,000 \\
\text { Btu/h capacity }\end{array}$ & & $\begin{array}{l}\text { AFUE 78\% } \\
\mathrm{E}_{\mathrm{t}} 80 \% \\
\text { (Table 503.2) }\end{array}$ & $\begin{array}{l}\text { Same (but see } \\
\text { comment at } \\
\text { right) }\end{array}$ & $\begin{array}{l}\text { DOE has issued a Notice of } \\
\text { Proposed Rulemaking } \\
\text { (NOPR) which will raise } \\
\text { minimum AFUE } \\
\text { requirements to } 80-83 \% \\
\text { depending upon product } \\
\text { type. }{ }^{5, * *}\end{array}$ \\
\hline $\begin{array}{l}\text { Gas-fired or oil-fired } \\
\text { steam and hot water } \\
\text { boilers; }<300,000 \\
\text { Btu/h capacity }\end{array}$ & & $\begin{array}{l}\text { AFUE } 80 \% \\
\text { (Table 503.2) }\end{array}$ & $\begin{array}{l}\text { Same (but see } \\
\text { comment at } \\
\text { right) }\end{array}$ & $\begin{array}{l}\text { DOE has issued a Notice of } \\
\text { Proposed Rulemaking } \\
\text { (NOPR) which will raise } \\
\text { minimum AFUE } \\
\text { requirements to } 83-84 \% \\
\text { depending upon product } \\
\text { type. }{ }^{5, * *}\end{array}$ \\
\hline \multirow[t]{2}{*}{$\begin{array}{l}\text { Electric water } \\
\text { heaters - NAECA } \\
\text { covered* }\end{array}$} & $\begin{array}{l}\text { Storage, } 20- \\
120 \text { gallon } \\
\text { storage } \\
\text { volume }(\mathrm{V}) \\
\end{array}$ & $\begin{array}{l}\text { Energy factor } \\
(\mathrm{EF}) \geq 0.93- \\
0.00132 \mathrm{~V} \\
(\text { Table } 504.2 .1)\end{array}$ & $\begin{array}{l}E F \geq 0.97- \\
0.00132 V\end{array}$ & Effective date $-1 / 20 / 2004^{6}$ \\
\hline & All other & $\begin{array}{l}\mathrm{EF} \geq 0.93- \\
0.00132 \mathrm{~V} \\
(\text { Table } 504.2 .1)\end{array}$ & Same & \\
\hline \multirow[t]{2}{*}{$\begin{array}{l}\text { Gas water heaters - } \\
\text { NAECA covered* }\end{array}$} & $\begin{array}{l}\text { Storage, } 20- \\
100 \text { gallon } \\
\text { storage } \\
\text { volume }(\mathrm{V}) \\
\end{array}$ & $\begin{array}{l}\mathrm{EF} \geq 0.62- \\
0.0019 \mathrm{~V} \\
(\text { Table 504.2.1) }\end{array}$ & $\begin{array}{l}E F \geq 0.67- \\
0.0019 \mathrm{~V}\end{array}$ & Effective date $-1 / 20 / 2004^{6}$ \\
\hline & All other & $\begin{array}{l}E F \geq 0.62- \\
0.0019 \mathrm{~V} \\
(\text { Table 504.2.1) }\end{array}$ & Same & \\
\hline $\begin{array}{l}\text { Oil water heaters - } \\
\text { NAECA covered }^{\text {a }}\end{array}$ & All & $\begin{array}{l}\mathrm{EF} \geq 0.59- \\
0.0019 \mathrm{~V} \text { (Table } \\
504.2 .1)\end{array}$ & Same & \\
\hline
\end{tabular}




\begin{tabular}{|l|l|l|l|l|}
\hline $\begin{array}{l}\text { Equipment } \\
\text { category }\end{array}$ & $\begin{array}{l}\text { Sub- } \\
\text { category }\end{array}$ & $\begin{array}{l}\text { IECC 2003 } \\
\text { efficiency } \\
\text { requirements }\end{array}$ & $\begin{array}{l}\text { Latest } \\
\text { minimum } \\
\text { Federal } \\
\text { requirements }\end{array}$ & Comments \\
\hline $\begin{array}{l}\text { Pool heaters - } \\
\text { NAECA covered* }\end{array}$ & $\begin{array}{l}\geq 78 \% \text { thermal } \\
\text { efficiency } \\
\text { (Table 504.2.1) }\end{array}$ & Same & Not \\
\hline $\begin{array}{l}\text { Non NAECA } \\
\text { covered water } \\
\text { heating equipment } \\
\text { and unfired storage } \\
\text { tanks }\end{array}$ & Table 504.2.1 & $\begin{array}{l}\text { Npecifically } \\
\text { mentioned in } \\
\text { IECC 2006, } \\
\text { section 403 } \\
\text { (residential) }\end{array}$ & $\begin{array}{l}\text { Only an issue in multi-unit } \\
\text { buildings with large central }\end{array}$ & HWstems \\
\hline $\begin{array}{l}* \text { DOE has just begun the process to revise the efficiency standards for water heaters, direct heating } \\
\text { equipment (gas-fired, vented heating products including vented hearth equipment), and pool heaters. } \\
\text { The current schedule calls for a final rule to be published in 2010. For electric storage water heating } \\
\text { equipment, heat pump water heater (HPWH) technology is currently on the list for evaluation in the } \\
\text { process. } \\
* * \text { Effective date likely to be three to five years after final rule is published. }\end{array}$ \\
\hline
\end{tabular}

\subsection{Heating and Cooling Equipment Sizing}

The 2003 IECC (Section 5.3.3.1) requires that system sizing be based upon building design loads calculated using procedures outlined in the ASHRAE Handbooks or with an approved equivalent procedure. Most local authorities accept (or even prefer) the Air Conditioning Contractors of America (ACCA) Manual J approach for load calculation as an "equivalent" procedure. ${ }^{7}$ The 2006 IECC (Section 403.6) refers to section M1401.3 of the International Residential Code which requires that equipment "be sized based on building loads calculated in accordance with ACCA Manual J or other approved heating and cooling load calculation methodologies." 8 Based on the foregoing, it may be assumed that heating and cooling equipment sizing requirements for the 2003 and 2006 IECC versions are equivalent.

\subsection{Duct and Pipe Insulation Requirements Review}

The 2006 IECC, Section 403.2.1, mandates that supply and return ducts be insulated to a minimum level of R-8. Ducts located in floor trusses (presumably above uninsulated basements or crawl spaces) are allowed a relaxed requirement of R-6, as shown in Table 6. Ducts within the conditioned space are not required to be insulated. ${ }^{\mathrm{c}}$ Compared to the requirements of the 2003 IECC (Section 503.3.3.3 and Table 503.3.3.3), this represents an increase in stringency (toward less energy use) in all buildings and locations for return ducts. However, for supply ducts the requirements are less stringent in many cases:

- Ducts in unconditioned attics or outside the building for climates with HDD $>7500$ (all of Zones 7 and 8 and most of Zone 6) - R-11 in 2003 vs. R-8 in 2006; and

\footnotetext{
${ }^{\mathrm{c}}$ M1601.3.4, subparagraph 1 of the 2006 International Residential Code requires a vapor retarder to be installed on the exterior of insulation on cooling supply ducts in "nonconditioned" spaces. That requirement is equivalent to that in footnote a to Table 503.3.3.3 in the 2003 IECC.
} 
- Ducts in floor trusses over unconditioned basements or crawlspaces for climates with HDD $>3500$ (all of Zones 4-8, much of Zones 3A and 3B, and part of Zone 3C) $-R-8$ to $R-11$ in 2003 vs. $R-6$ in 2006.

Section 503.3.3.1 and Table 503.3.3.1 of the 2003 IECC specify pipe insulation thickness as a function of fluid content temperature and pipe diameter; the resulting ranges are summarized in Table 6. The 2006 IECC, Section 403.3, mandates that pipes for heating or cooling fluid circulation $(>105 \mathrm{~F}$ or $<55 \mathrm{~F})$ be insulated to a minimum level of R-2. Compared to the requirements in the 2003 IECC ( $\underline{\boldsymbol{R}-2}$ to $\boldsymbol{R}-14)$, this represents a significant decrease in stringency (toward greater energy use), especially for large systems with large pipe sizes and systems circulating fluids in excess of $200 \mathrm{~F}$.

Section 504.5 and Table 504.5 of the 2003 IECC mandate insulation levels for circulating hot service water pipes, as shown in Table 6. Section 403.4 of the 2006 IECC mandates a minimum insulation level of R-2 for circulating hot water system pipes; no insulation levels are mandated for noncirculating hot water system runouts. Compared to the 2003 IECC requirements, this represents a decrease in stringency, especially for large systems and systems that circulate water at temperatures above $170 \mathrm{~F}$.

Table 6 Pipe and Duct Insulation Comparison

\begin{tabular}{|c|c|c|}
\hline & 2003 & 2006 \\
\hline \multicolumn{3}{|l|}{ Ducts } \\
\hline Return ducts & R-0 to R-6 & \multirow{4}{*}{$\begin{array}{l}\mathrm{R}-8, \mathrm{R}-6 \text { in } \\
\text { floor trusses }\end{array}$} \\
\hline Supply ducts in unconditioned attics or outside building & R-8 to R-11 & \\
\hline Supply ducts in other unconditioned spaces, HDD $\leq 3500$ & R-4 to R-6 & \\
\hline Supply ducts in other unconditioned spaces, HDD $>3500$ & R-8 to R-11 & \\
\hline \multicolumn{3}{|c|}{ Pipes for heating or cooling fluid circulation for HVAC systems } \\
\hline Fluid temperature $<55 \mathrm{~F}$ & R-2 to R-6 & \multirow{4}{*}{$\mathrm{R}-2$} \\
\hline Fluid temperature 106 to $200 \mathrm{~F}$ & R-2 to R-6 & \\
\hline Fluid temperature $>200 \mathrm{~F}$ & R-4 to R-14 & \\
\hline Condensate return & R-4 to R-8 & \\
\hline \multicolumn{3}{|c|}{ Pipes for circulating hot service water systems } \\
\hline Non-circulating run-outs & R-2 & None \\
\hline Circulating mains and runouts, hot water temperature $<170 \mathrm{~F}$ & $\mathrm{R}-2$ to $\mathrm{R}-6$ & \multirow{2}{*}{$\mathrm{R}-2$} \\
\hline Circulating mains and runouts, hot water temperature $\geq 170 \mathrm{~F}$ & $\mathrm{R}-4$ to $\mathrm{R}-8$ & \\
\hline
\end{tabular}

\subsection{Duct Sealing Requirements}

The 2006 IECC, section 403.2.2, requires that all portions of the air distribution system be sealed (ducts, building cavities used as ducts, air handlers, etc.). Joints and seams must comply with the requirements of section M1601.3 of the International Residential Code which are generally equivalent to those found in section 503.3.4.3 of the 2003 IECC. The 2006 IECC adds a specific treatment of building cavities used as ducts, first requiring that such cavities are subject to duct sealing requirements, and second, forbidding their use as supply ducts. Based on the foregoing, it may be assumed that the duct sealing requirements of the 2003 and 2006 versions of the IECC are equivalent, but that the discussion scope is improved. 


\subsection{Ventilation Requirements}

Both the 2003 IECC, section 503.3.3.5, and the 2006 IECC, section 403.5, require the installation of automatic or gravity dampers to close all outdoor air intakes and exhausts when the ventilation system is not operating. The 2003 IECC also required the installation of an accessible on-off switch for the ventilation system, but the 2006 IECC does not. This change is not likely to impact the energy efficiency of the building, but may represent a security issue with regard to the ability to isolate the building air from an external air-borne contaminant threat.

Building energy consumption is also influenced by ventilation rates. Therefore, changes in ventilation requirements between 2003 and 2006 were examined. Since 2003, ventilation rates for single-family and low-rise (three stories above grade or less) multi-unit residential buildings have been governed by ASHRAE Standard 62.2. Standard 62.2 was first issued in 2003 and a revised version was issued in 2004; however, the whole building ventilation requirements are equivalent in both versions. ${ }^{9,10}$ For high-rise multi-unit residential buildings, ventilation rates were covered under ASHRAE Standard 62-2001 prior to 2004 and by ASHRAE Standard 62.1 after 2004 - requirements in these documents for residential buildings are equivalent. ${ }^{11,12}$ So it may be assumed that the ventilation requirements for residential buildings in both the 2003 and 2006 IECC versions are equivalent. 


\section{General Code Review}

In the course of this review, a side-by-side comparison of the 2003 and 2006 IECC was made. That comparison is summarized in Table 7 to aid the user in navigating between the 2003 and 2006 IECC. The single most noticeable feature of this side-by-side comparison is the improved organization and text in the 2006 IECC compared to the 2003 IECC. While many of the topics listed in Table 7 have been addressed previously in this report, a few have not:

- The definitions, included in section 202 of both the 2003 and 2006 IECC, for conditioned space and skylights have been changed, as described in Table 7.

- The construction documentation has been expanded.

- The $2006 \mathrm{R}$-value computation discussion is more explicit, which should be more enforceable.

- The 2006 IECC provides a common-language list of wall types that qualify as 'mass walls', compared to the use of wall heat capacity values in the 2003 IECC.

- The 2006 IECC air leakage discussion is much the same as the 2003 IECC, but 2006 IECC has an improved list of locations including site-built windows.

These changes will tend to improve the stringency of the 2006 IECC relative to the 2003 IECC.

- The 2003 IECC included a lighting power restriction for the public portion of multi-unit residential buildings; the 2006 IECC does not.

This change will tend to decrease the stringency of the 2006 IECC relative to the 2003 IECC.

Table 7 IECC Sectional Review

\begin{tabular}{|c|c|c|}
\hline 2003 & 2006 & Topic \\
\hline $\begin{array}{l}101.2 .2 .1 \\
502.2 .5\end{array}$ & 101.4 .3 & $\begin{array}{l}\text { Additions: Both codes require that additions comply with the same requirements } \\
\text { as a new building. The } 2003 \text { IECC also provides a separate table (Table } 502.2 .5 \text { ) } \\
\text { with a prescriptive option for additions }<500 \mathrm{ft}^{2} \text {. This option was not evaluated } \\
\text { in this comparison. }\end{array}$ \\
\hline 102.5 .1 .1 & $\begin{array}{l}102.1 .1 . \\
1\end{array}$ & $\begin{array}{l}\text { Added spray polyurethane to identification section - an appropriate change } \\
\text { reflecting increased use of this product in the residential sector. }\end{array}$ \\
\hline 102.5 .2 & 102.1 .3 & Fenestration default factors: see discussion in Section 2.6 and Table 4. \\
\hline 104.2 & 104.2 & $\begin{array}{l}\text { Construction documentation has been expanded to include air-sealing and } \\
\text { duct insulation. }\end{array}$ \\
\hline 202 & 202 & $\begin{array}{l}\text { Definitions: Conditioned space was defined by comfort in the } 2003 \text { IECC; the } \\
2006 \text { IECC includes spaces containing uninsulated ducts. This will serve to } \\
\text { expand the scope of the conditioned-space envelope and will therefore increase } \\
\text { the stringency of the } 2006 \text { IECC relative to the } 2003 \text { IECC. The addition of } \\
\text { "vapor retarder" may indirectly improve energy efficiency. The definition of a } \\
\text { skylight was tightened based upon the angle; this may reduce the number of } \\
\text { skylights subject to the reduction in U-value stringency discussed in Section } 2.5 \text {. }\end{array}$ \\
\hline 502.2.4.6 & 402.1 .1 & Opaque doors: See Section 2.6 discussion. \\
\hline 502.2 .4 .2 & 402.1 .1 & Wood, mass, and metal-framed walls. See Section 2 discussions. \\
\hline 502.1 .5 & $\begin{array}{l}402.1 .1 \\
\text { table }\end{array}$ & SHGC: See Section 2.6 discussion. \\
\hline 502.2 .4 .1 & 402.1 .2 & $\begin{array}{l}\text { R-value computation: The } 2006 \text { IECC is more explicit which should be more } \\
\text { enforceable. }\end{array}$ \\
\hline
\end{tabular}




\begin{tabular}{|c|c|c|}
\hline 2003 & 2006 & Topic \\
\hline 502.2 & 402.1 .3 & $\begin{array}{l}\text { Equivalent assembly U-value alternative to insulation R-values, convenient and } \\
\text { flexible, needed for 402.1.4. }\end{array}$ \\
\hline 502.2 .4 .5 & 402.2 .1 & Truss/raised heel attic construction: See Section 2.3 discussion. \\
\hline 502.2 .4 .7 & 402.2 .2 & Ceiling insulation: See Section 2.3 discussion. \\
\hline 502.2 .4 .17 & 402.2 .3 & $\begin{array}{l}\text { Mass walls: } 2003 \text { IECC defines a mass wall according to its heat capacity; the } \\
2006 \text { IECC provides a common language list of wall types that qualify. See } \\
\text { Section } 2.4 \text { discussion. }\end{array}$ \\
\hline $\begin{array}{l}502.2 .4 .16 \\
502.2 .4 .18 \\
502.2 .4 .19\end{array}$ & 402.2 .4 & Steel frame walls, ceiling, floor. See Section 2.5 discussion. \\
\hline 502.2 .4 .8 & 402.2 .5 & Floor insulation. See Section 2.2 discussion. \\
\hline 502.2 .4 .9 & 402.2 .6 & Basement walls. See Section 2.2 discussion. \\
\hline $\begin{array}{l}502.2 .4 .10 \\
502.2 .4 .11\end{array}$ & 402.2.7, & Slab insulation. See Section 2.2 discussion. \\
\hline 502.2 .4 .12 & 402.2 .8 & Crawl space walls. See Section 2.2 discussion. \\
\hline 502.1 .2 & 402.2 .9 & Masonry veneer accommodation unchanged. \\
\hline 502.2 .4 .3 & 402.3 .1 & $\begin{array}{l}\text { Area-weighted average fenestration U-factor allowed for 2006, required for } \\
2003 \text {. }\end{array}$ \\
\hline 502.2 .4 .4 & 402.3 .3 & $\begin{array}{l}\text { Fenestration exemption: } 2003 \text { exempts U-factor for up to } 1 \% \text { of total glazing; } \\
2006 \text { exempts } 15 \mathrm{ft}^{2} \text { and refers to both U-factor and SHGC. }\end{array}$ \\
\hline 502.2 .5 & 402.3 .6 & $\begin{array}{l}\text { Replacement fenestration: similar match of U and SHGC; } 2003 \text { also required } \\
\text { that the air leakage rating should match. }\end{array}$ \\
\hline 502.2 .5 & $\begin{array}{l}402.2 .10 \\
402.3 .5 \\
\end{array}$ & Isolated sunrooms: not evaluated in this comparison. \\
\hline $\begin{array}{l}502.1 .4 .1 \\
502.1 .4 .2\end{array}$ & $\begin{array}{l}402.4 \\
402.4 .1\end{array}$ & $\begin{array}{l}\text { Air leakage discussion is much the same, but } 2006 \text { IECC has an improved list of } \\
\text { locations including site-built windows. Terminology updates include "house } \\
\text { wrap" in 2003, "air barrier" in } 2006 .\end{array}$ \\
\hline 502.1 .3 & 402.4 .3 & Recessed lights - same except moved from moisture control to air leakage. \\
\hline 502.1 .1 & 402.5 & $\begin{array}{l}\text { Moisture control discussion is very similar, although } 2003 \text { IECC specified the } \\
\text { max perm rating allowable for a vapor retarder. }\end{array}$ \\
\hline $\begin{array}{l}503.3 .6 \\
503.3 .7\end{array}$ & & Mechanical system transport energy and balancing: See Section 3 discussion. \\
\hline 504.3 & & Swimming pool heater conservation measures: See Section 3 discussion. \\
\hline 504.6 & & Low-flow shower heads: See Section 3 discussion. \\
\hline $\begin{array}{l}503.3 .3 .3 \\
503.3 .3 .4\end{array}$ & $\begin{array}{l}403.2 .1 \\
403.2 .2 \\
403.2 .3\end{array}$ & Duct insulation. See Section 3 discussion. \\
\hline 503.3 .3 .1 & 403.3 & Pipe insulation. See Section 3 discussion. \\
\hline 504 & 403.4 & $\begin{array}{l}\text { Water heating and combined hydronic systems insulation. See Section } 3 \\
\text { discussion. }\end{array}$ \\
\hline 503.3 .3 .5 & 403.5 & Mechanical ventilation: See Section 3 discussion. \\
\hline 505.2 & - & $\begin{array}{l}\text { Lighting power budget deleted. This would remove the restrictions for the } \\
\text { public areas of the } R-2 \text { buildings. }\end{array}$ \\
\hline 301 & 901 & Climate zones all new. See Section 2 discussion. \\
\hline
\end{tabular}




\section{Conclusions}

This report was prepared to answer the question; did the 2006 revision to the IECC improve energy efficiency in residential buildings compared to the 2003 IECC? A quantitative analysis, which would entail assembling housing construction completion data by type and climate, assessing the impacts of the IECC revision on these various buildings, and weighting the various buildings to estimate the aggregate residential impact was beyond the scope of this review. Perhaps the code development process itself has generated and documented aggregate residential impacts in technical support documents, but our review was limited to the 2003 and 2006 versions of the IECC, and other related federal standards.

The conclusion from the qualitative review is that enough 2006 requirements are relaxed when compared to 2003, that there is a "reasonable doubt" as to whether energy efficiency in residential buildings will have been improved as a result of the 2006 IECC revision. Although some residential buildings may be more efficient, many will be unchanged or less efficient. Some of the most important points that lead to this conclusion are:

- Changes that may lead to more efficient residential buildings:

- The 2006 IECC is much easier to comprehend than the 2003 IECC, which may lead to improved compliance.

- Minimum levels of ceiling and wall insulation were increased for very warm climates.

- The maximum SHGC for hot climates now applies to a broader geographic region.

- For small multi-unit buildings, the envelope R-values and window U-factors have both been made more stringent.

- Changes that may lead to less efficient residential buildings:

- There are mixed changes to the building envelope requirements, but for one- and two-family dwellings there is a general impression of reduced building envelope stringency with regard to both insulation $R$-values and glazing $U$-factors, as was summed up in Figure 1 and Table 1. A qualitative assessment of the blue-shaded changes sections in Appendices A and B shows more red (indicating less stringency) than black (indicating more stringency), and many of these reductions apply to heavily populated climate zones.

- The ability to use lower levels of floor insulation so long as the joist is filled, or to use a lower level of ceiling insulation for a specified area are two more contributing factors.

- There is a reduced insulation requirement for many supply ducts and pipes. Reduced pipe insulation could be important for hydronic heated buildings in the North, especially for the R-2 building class.

This comparison of the 2003 and 2006 IECC can also be used to identify potential targets for future IECC revision cycles. A small number of changes to the R-value requirements would make a significant change in the conclusions reached here. In particular, code review teams may want to consider increasing the ceiling insulation requirements for Zones 3 and 5 , increasing the wall insulation requirements for Zones 5 through 8 , and revisiting the duct and pipe insulation 
requirements. The change in climate zones to place more emphasis on cooling loads should be helpful in future code revisions. 


\section{References}

${ }^{1}$ International Energy Conservation Code, International Code Council, Inc., Country Club Hills, IL, 2006

2 42USC6833

${ }^{3}$ P. Cole and T. Taylor, "Energy Conservation Code Decoded,", Home Energy , September/October 2006, www.homeenergy.org

${ }^{4}$ DOE 10 CFR Part 430, Subpart C, Section 430.32 as amended per Federal Register/Vol 66, \#14/January 22, 2001/pp 7170-7200.

${ }^{5}$ Federal Register/Vol 71, \#194/October 6, 2006/pp 59240-59259.

${ }^{6}$ DOE 10 CFR Part 430, Appendix E to Subpart B as amended per Federal Register/Vol 66, \#11/January 17, 2001/pp 4474-4497.

7 ACCA Manual J, "Residential Load Calculation - Eighth Edition."

${ }^{8}$ International Residential Code, International Code Council, Inc., Country Club Hills, IL, 2006

9 ANSI/ASHRAE Standard 62.2-2003, "Ventilation and Acceptable Indoor Air Quality in LowRise Residential Buildings."

${ }^{10}$ ANSI/ASHRAE Standard 62.2-2004, "Ventilation and Acceptable Indoor Air Quality in LowRise Residential Buildings."

${ }^{11}$ ANSI/ASHRAE Standard 62-2001, "Ventilation for Acceptable Indoor Air Quality."

12 ANSI/ASHRAE Standard 62.1-2004, "Ventilation for Acceptable Indoor Air Quality." 


\section{Appendix A: Changes in Envelope R-Values}

Table A.1 Ceiling, Wall, and Floor Insulation R-Values for Detached One- and Two- Family Dwellings

\begin{tabular}{|c|c|c|c|c|c|c|c|c|c|c|c|}
\hline \multirow[t]{3}{*}{ Table A.1.1 } & \multirow{3}{*}{\multicolumn{2}{|c|}{$\begin{array}{l}\text { Climate } \\
\text { Zone }\end{array}$}} & \multicolumn{3}{|c|}{ Ceiling } & \multicolumn{3}{|c|}{ Wall } & \multicolumn{3}{|c|}{ Floor } \\
\hline & & & \multicolumn{9}{|c|}{ Window to Wall Area Ratio } \\
\hline & & & $15 \%$ & $20 \%$ & $25 \%$ & $15 \%$ & $20 \%$ & $25 \%$ & $15 \%$ & $20 \%$ & $25 \%$ \\
\hline \multirow[t]{7}{*}{2003 IECC } & \multicolumn{2}{|c|}{1} & $\mathrm{R}-13$ & $\mathrm{R}-19$ & R-30 & $\mathrm{R}-11$ & $\mathrm{R}-11$ & $\mathrm{R}-11$ & $\mathrm{R}-11$ & $\mathrm{R}-11$ & $\mathrm{R}-11$ \\
\hline & \multicolumn{2}{|c|}{2} & R-19 & $\mathrm{R}-30$ & $\mathrm{R}-30$ & $\mathrm{R}-11$ & $\mathrm{R}-13$ & $\mathrm{R}-13$ & $\mathrm{R}-11$ & $\mathrm{R}-11$ & $\mathrm{R}-11$ \\
\hline & \multicolumn{2}{|c|}{3} & $\mathrm{R}-19$ & $\mathrm{R}-30$ & $R-30$ & $\mathrm{R}-11$ & $\mathrm{R}-13$ & $\mathrm{R}-13$ & $\mathrm{R}-11$ & $\mathrm{R}-11$ & $\mathrm{R}-11$ \\
\hline & \multicolumn{2}{|c|}{4} & $\mathrm{R}-26$ & $\mathrm{R}-30$ & $\mathrm{R}-30$ & $R-13$ & $\mathrm{R}-13$ & $R-13$ & $\mathrm{R}-11$ & $\mathrm{R}-11$ & $R-13$ \\
\hline & \multicolumn{2}{|c|}{5} & R-30 & R-38 & $\mathrm{R}-38$ & $\mathrm{R}-13$ & $\mathrm{R}-13$ & $\mathrm{R}-13$ & $\mathrm{R}-11$ & $\mathrm{R}-11$ & R-19 \\
\hline & \multicolumn{2}{|c|}{6} & $R-30$ & R-38 & $R-38$ & $R-13$ & $R-13$ & $R-16$ & $R-19$ & $R-19$ & R-19 \\
\hline & \multicolumn{2}{|c|}{7} & R-30 & R-38 & R-38 & $\mathrm{R}-13$ & $\mathrm{R}-13$ & $\mathrm{R}-19$ & $\mathrm{R}-19$ & $\mathrm{R}-19$ & R-19 \\
\hline 2006 IECC & \multicolumn{2}{|c|}{$\frac{1}{2}$} & \multicolumn{3}{|c|}{ R-30 } & \multicolumn{3}{|c|}{$\mathrm{R}-13$} & \multicolumn{3}{|c|}{$\mathrm{R}-13$} \\
\hline \multicolumn{12}{|c|}{$\begin{array}{l}\text { Difference between } 2003 \text { and } 2006 \text { IECC - Increased stringency in bold Black, decreased stringency in bold (Red), and } \\
\text { no change in stringency is blank. }\end{array}$} \\
\hline States associated with climate zones & 2003 & 2006 & \multicolumn{3}{|c|}{ Ceiling } & \multicolumn{3}{|c|}{ Wall } & \multicolumn{3}{|c|}{ Floor } \\
\hline $\begin{array}{r}\text { AS, FL, FM, GU, HI, MH, MP, PR, } \\
\text { PW, VI }\end{array}$ & 1 & 1 & R-17 & R-11 & & R-2 & R-2 & $\mathbf{R}-2$ & $\mathbf{R}-2$ & $\mathbf{R}-2$ & R-2 \\
\hline $\mathrm{FL}$ & 1 & \multirow{7}{*}{2} & R-17 & R-11 & & R-2 & R-2 & R-2 & R-2 & R-2 & R-2 \\
\hline $\mathrm{FL}, \mathrm{TX}$ & 2 & & R-11 & & & R-2 & & & R-2 & R-2 & R-2 \\
\hline $\mathrm{AZ}, \mathrm{CA}, \mathrm{FL}, \mathrm{LA}, \mathrm{TX}$ & 3 & & R-11 & & & $\mathbf{R}-\mathbf{2}$ & & & $\mathbf{R}-2$ & R-2 & R-2 \\
\hline $\mathrm{AL}, \mathrm{AZ}, \mathrm{FL}, \mathrm{GA}, \mathrm{LA}, \mathrm{MS}, \mathrm{TX}$ & 4 & & R-4 & & & & & & R-2 & R-2 & \\
\hline GA, LA, TX & 5 & & & $(\mathrm{R}-8)$ & (R-8) & & & & R-2 & R-2 & $(\mathrm{R}-6)$ \\
\hline GA & 6 & & & $(\mathrm{R}-8)$ & (R-8) & & & $(\mathrm{R}-3)$ & $(\mathrm{R}-6)$ & $(R-6)$ & $(\mathrm{R}-6)$ \\
\hline GA & 7 & & & (R-8) & (R-8) & & & $(\mathrm{R}-6)$ & (R-6) & $(\mathrm{R}-6)$ & (R-6) \\
\hline
\end{tabular}




\begin{tabular}{|c|c|c|c|c|c|c|c|c|c|c|}
\hline \multirow[t]{3}{*}{ Table A.1.2 } & \multirow{3}{*}{$\begin{array}{l}\text { Climate } \\
\text { Zone }\end{array}$} & \multicolumn{3}{|c|}{ Ceiling } & \multicolumn{3}{|c|}{ Wall } & \multicolumn{3}{|c|}{ Floor } \\
\hline & & \multicolumn{9}{|c|}{ Window to Wall Area Ratio } \\
\hline & & $15 \%$ & $20 \%$ & $25 \%$ & $15 \%$ & $20 \%$ & $25 \%$ & $15 \%$ & $20 \%$ & $25 \%$ \\
\hline \multirow[t]{8}{*}{2003 IECC } & 3 & R-19 & $\mathrm{R}-30$ & R-30 & $R-11$ & R-13 & $\mathrm{R}-13$ & $R-11$ & $\mathrm{R}-11$ & $\mathrm{R}-11$ \\
\hline & 4 & R-26 & R-30 & R-30 & $\mathrm{R}-13$ & $\mathrm{R}-13$ & $\mathrm{R}-13$ & $\mathrm{R}-11$ & $\mathrm{R}-11$ & $\mathrm{R}-13$ \\
\hline & 5 & R-30 & R-38 & R-38 & $\mathrm{R}-13$ & R-13 & $\mathrm{R}-13$ & $\mathrm{R}-11$ & $\mathrm{R}-11$ & R-19 \\
\hline & 6 & R-30 & $\mathrm{R}-38$ & $\mathrm{R}-38$ & $\mathrm{R}-13$ & $\mathrm{R}-13$ & $\mathrm{R}-16$ & $\mathrm{R}-19$ & $\mathrm{R}-19$ & R-19 \\
\hline & 7 & $\mathrm{R}-30$ & R-38 & $\mathrm{R}-38$ & $\mathrm{R}-13$ & $\mathrm{R}-13$ & $\mathrm{R}-19$ & $\mathrm{R}-19$ & $\mathrm{R}-19$ & $\mathrm{R}-19$ \\
\hline & 8 & R-30 & R-38 & R-38 & $R-13$ & R-13 & R-19 & R-19 & R-19 & R-19 \\
\hline & 9 & R-38 & R-38 & $R-38$ & R-13 & R-13 & R-19 & R-19 & R-19 & R-19 \\
\hline & 10 & R-38 & R-38 & R-38 & $R-16$ & R-16 & R-19 & $R-19$ & R-19 & R-19 \\
\hline 2006 IECC & 3 & \multicolumn{3}{|c|}{ R-30 } & \multicolumn{3}{|c|}{$R-13$} & \multicolumn{3}{|c|}{$R-19$} \\
\hline
\end{tabular}

Difference between 2003 and 2006 IECC - Increased stringency in bold Black, decreased stringency in bold (Red), and no change in stringency is blank.

\begin{tabular}{|c|c|c|c|c|c|c|c|c|c|c|c|}
\hline States associated with climate zones & 2003 & 2006 & & eiling & & & Wall & & & oor & \\
\hline $\mathrm{AZ}, \mathrm{CA}$ & 3 & & $\mathbf{R}-11$ & & & R-2 & & & $\mathbf{R}-\mathbf{8}$ & $\mathbf{R}-\mathbf{8}$ & R-8 \\
\hline$A L, A Z, C A, M S$ & 4 & & R-4 & & & & & & R-8 & R-8 & R-6 \\
\hline $\mathrm{AL}, \mathrm{CA}, \mathrm{GA}, \mathrm{LA}, \mathrm{MS}, \mathrm{NV}, \mathrm{SC}, \mathrm{TX}$ & 5 & & & $(\mathrm{R}-8)$ & (R-8) & & & & R-8 & R-8 & \\
\hline $\begin{array}{r}\mathrm{AL}, \mathrm{AZ}, \mathrm{AR}, \mathrm{CA}, \mathrm{GA}, \mathrm{LA}, \mathrm{MS}, \mathrm{NC}, \mathrm{OK}, \mathrm{SC}, \\
\mathrm{TX}\end{array}$ & 6 & 3 & & $(\mathrm{R}-8)$ & $(\mathrm{R}-8)$ & & & $(\mathrm{R}-3)$ & & & \\
\hline $\begin{array}{r}A L, A Z, A R, G A, M S, N M, N C, O K, S C, T N, \\
T X \\
\end{array}$ & 7 & 3 & & (R-8) & $(\mathrm{R}-8)$ & & & $(\mathrm{R}-6)$ & & & \\
\hline $\mathrm{AL}, \mathrm{AR}, \mathrm{CA}, \mathrm{GA}, \mathrm{NC}, \mathrm{OK}, \mathrm{TN}$ & 8 & & & $(\mathrm{R}-8)$ & (R-8) & & & $(\mathrm{R}-6)$ & & & \\
\hline OK, TN, TX & 9 & & $(\mathrm{R}-8)$ & $(\mathrm{R}-8)$ & $(\mathrm{R}-8)$ & & & $(\mathrm{R}-6)$ & & & \\
\hline UT & 10 & & (R-8) & (R-8) & $(\mathrm{R}-8)$ & (R-3) & $(\mathrm{R}-3)$ & (R-6) & & & \\
\hline
\end{tabular}




\begin{tabular}{|c|c|c|c|c|c|c|c|c|c|c|}
\hline \multirow[t]{2}{*}{ Table A.1.3 } & \multirow{2}{*}{$\begin{array}{l}\text { Climate } \\
\text { Zone }\end{array}$} & \multicolumn{3}{|c|}{ Ceiling } & \multicolumn{3}{|c|}{ Wall } & \multicolumn{3}{|c|}{ Floor } \\
\hline & & \multicolumn{9}{|c|}{ Window to Wall Area Ratio } \\
\hline \multirow[t]{4}{*}{2003 IECC } & 5 & $\mathrm{R}-30$ & $\mathrm{R}-38$ & R-38 & $\mathrm{R}-13$ & $\mathrm{R}-13$ & $\mathrm{R}-13$ & $\mathrm{R}-11$ & $\mathrm{R}-11$ & $\mathrm{R}-19$ \\
\hline & 8 & $\mathrm{R}-30$ & R-38 & R-38 & $\mathrm{R}-13$ & $\mathrm{R}-13$ & $\mathrm{R}-19$ & $\mathrm{R}-19$ & $\mathrm{R}-19$ & $\mathrm{R}-19$ \\
\hline & 9 & R-38 & $\mathrm{R}-38$ & $\mathrm{R}-38$ & $\mathrm{R}-13$ & $\mathrm{R}-13$ & $\mathrm{R}-19$ & $\mathrm{R}-19$ & $\mathrm{R}-19$ & R-19 \\
\hline & 10 & $\mathrm{R}-38$ & R-38 & $\mathrm{R}-38$ & $\mathrm{R}-16$ & $\mathrm{R}-16$ & $\mathrm{R}-19$ & $\mathrm{R}-19$ & $\mathrm{R}-19$ & $\mathrm{R}-19$ \\
\hline \multirow[t]{2}{*}{2006 IECC } & 4 & \multirow{2}{*}{\multicolumn{3}{|c|}{ R-38 }} & \multicolumn{3}{|c|}{$\mathrm{R}-13$} & \multicolumn{3}{|c|}{ R-19 } \\
\hline & 4 Marine & & & & \multicolumn{3}{|c|}{ R-19 } & \multicolumn{3}{|c|}{ R-30 } \\
\hline
\end{tabular}

Difference between 2003 and 2006 IECC - Increased stringency in bold Black, decreased stringency in bold (Red), and no change in stringency is blank.

\begin{tabular}{|c|c|c|c|c|c|c|c|c|c|c|}
\hline States associated with climate zones & 2003 & 2006 & \multicolumn{2}{|r|}{ Ceiling } & \multicolumn{3}{|c|}{ Wall } & \multicolumn{3}{|c|}{ Floor } \\
\hline GA & 5 & \multirow{7}{*}{4} & R-8 & & & & & R-8 & R-8 & \\
\hline GA, NC & 7 & & R-8 & & & & (R-6) & & & \\
\hline $\mathrm{AZ}, \mathrm{AR}, \mathrm{CA}, \mathrm{GA}, \mathrm{NM}, \mathrm{NC}, \mathrm{TN}, \mathrm{TX}, \mathrm{VA}$ & 8 & & R-8 & & & & (R-6) & & & \\
\hline $\begin{array}{r}\mathrm{AR}, \mathrm{CA}, \mathrm{DE}, \mathrm{KA}, \mathrm{KY}, \mathrm{MD}, \mathrm{MO}, \mathrm{NM}, \mathrm{NC}, \mathrm{TN}, \\
\mathrm{TX}, \mathrm{VA}\end{array}$ & 9 & & & & & & $(\mathrm{R}-6)$ & & & \\
\hline $\begin{array}{r}\text { AZ, DE, DC, IL, IN, KA, KY, MD, MO, NJ, NM, } \\
\text { NY, OK, PA, TN, VA, WV }\end{array}$ & 10 & & & & (R-3) & $(\mathrm{R}-3)$ & (R-6) & & & \\
\hline $\begin{array}{r}\mathrm{CO}, \mathrm{IL}, \mathrm{IN}, \mathrm{KA}, \mathrm{KY}, \mathrm{MD}, \mathrm{MO}, \mathrm{NJ}, \mathrm{NM}, \mathrm{NY} \\
\mathrm{OH}, \mathrm{PA}, \mathrm{VA}, \mathrm{WV}\end{array}$ & 11 & & & & (R-5) & (R-6) & (R-6) & & & \\
\hline MD, MO, NM, NY & 12 & & & $(\mathrm{R}-11)$ & (R-5) & (R-7) & $(\mathrm{R}-6)$ & $(\mathrm{R}-2)$ & & $(\mathrm{R}-2)$ \\
\hline CA, OR & 9 & & & & R-6 & R-6 & & R-11 & R-11 & R-11 \\
\hline OR, WA & 10 & $4 \mathrm{M}$ & & & R-3 & R-3 & & R-11 & R-11 & R-11 \\
\hline OR, WA & 11 & & & & R-1 & & & R-11 & R-11 & R-11 \\
\hline WA & 12 & & & (R-11) & R-1 & (R-1) & & R-9 & R-11 & R-9 \\
\hline
\end{tabular}




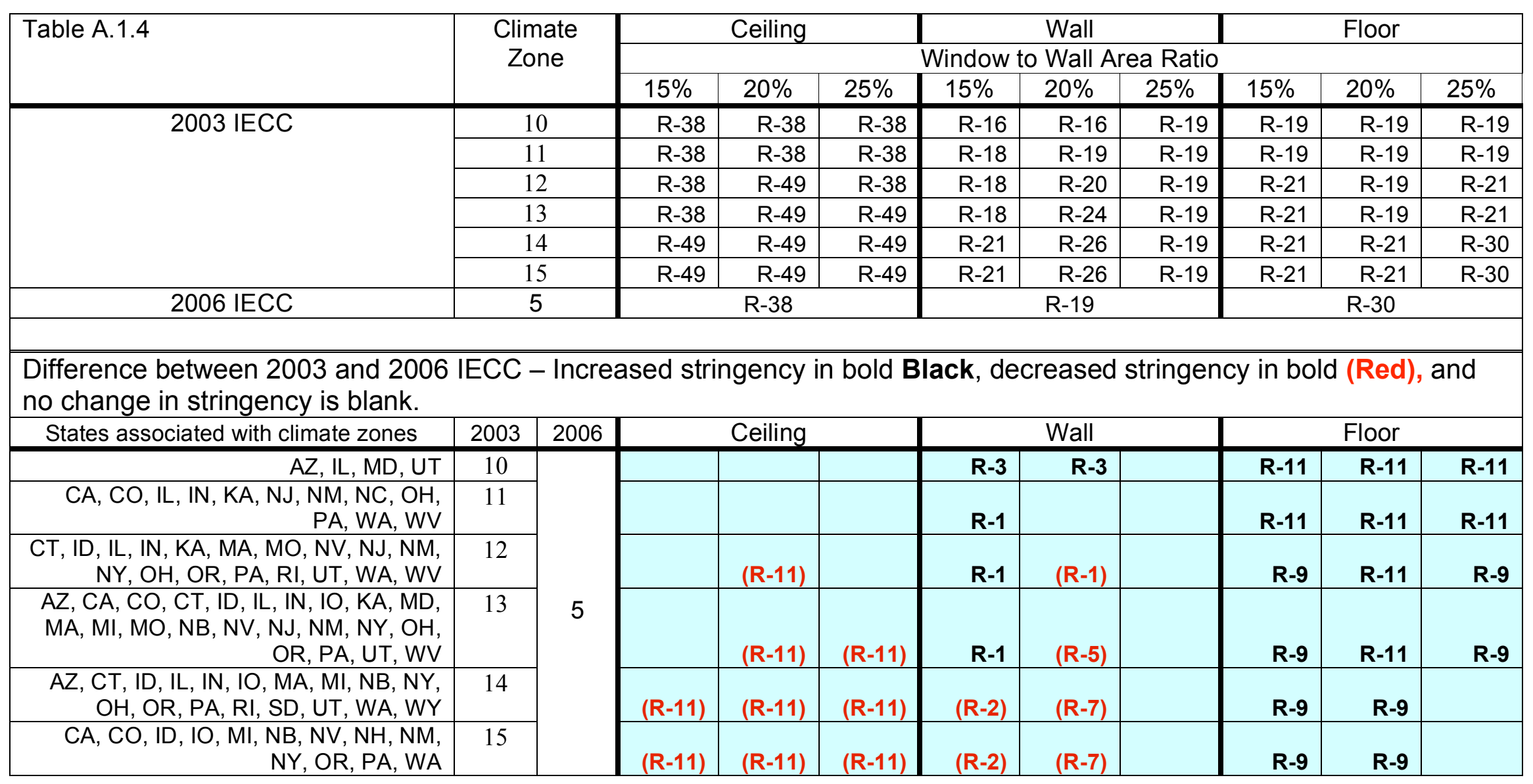




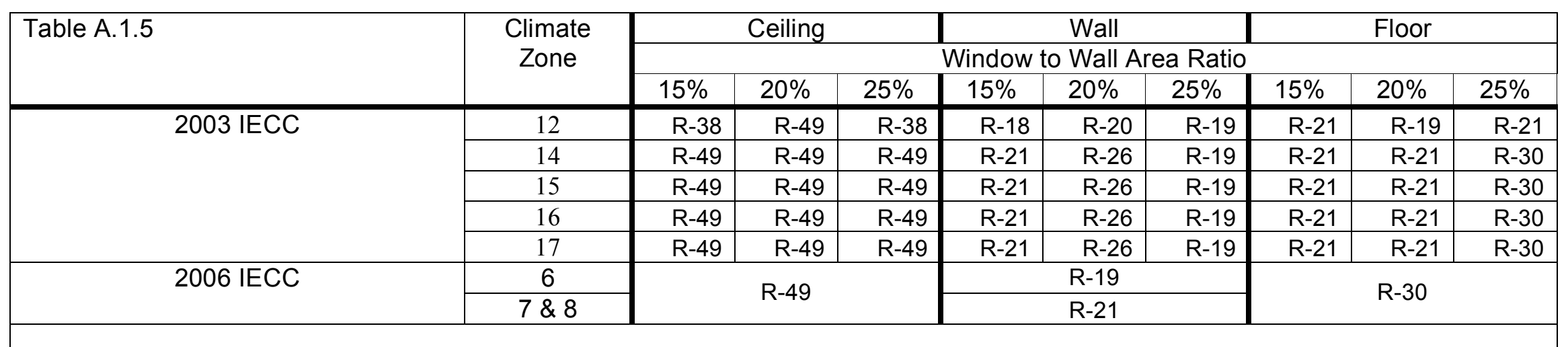

Difference between 2003 and 2006 IECC - Increased stringency in bold Black, decreased stringency in bold (Red), and no change in stringency is blank.

\begin{tabular}{|c|c|c|c|c|c|c|c|c|c|c|}
\hline States associated with climate zones & 2003 & 2006 & \multicolumn{2}{|c|}{ Ceiling } & \multicolumn{3}{|c|}{ Wall } & \multicolumn{3}{|c|}{ Floor } \\
\hline UT & 12 & \multirow{5}{*}{6} & R-11 & $\mathbf{R}-11$ & R-1 & $(\mathrm{R}-1)$ & & R-9 & $\mathbf{R}-11$ & R-9 \\
\hline $\mathrm{MI}, \mathrm{NY}$ & 14 & & & & $(\mathrm{R}-2)$ & (R-7) & & R-9 & R-9 & \\
\hline $\begin{array}{r}\mathrm{CA}, \mathrm{CO}, \mathrm{ID}, \mathrm{IO}, \mathrm{ME}, \mathrm{MI}, \mathrm{MN}, \mathrm{MT}, \mathrm{NH} \\
\mathrm{NY}, \mathrm{PA}, \mathrm{SD}, \mathrm{VT}, \mathrm{WA}, \mathrm{WI}, \mathrm{WY}\end{array}$ & 15 & & & & $(\mathrm{R}-2)$ & $(\mathrm{R}-7)$ & & R-9 & R-9 & \\
\hline $\begin{array}{r}\mathrm{CO}, \mathrm{ID}, \mathrm{ME}, \mathrm{MI}, \mathrm{MN}, \mathrm{MT}, \mathrm{NH}, \mathrm{NY}, \mathrm{ND}, \\
\mathrm{SD}, \mathrm{VT}, \mathrm{WI}, \mathrm{WY}\end{array}$ & 16 & & & & $(\mathbf{R}-2)$ & (R-7) & & R-9 & R-9 & \\
\hline ME, MN & 17 & & & & (R-2) & (R-7) & & R-9 & R-9 & \\
\hline $\mathrm{AK}, \mathrm{MI}, \mathrm{MN}$ & 16 & 78 & & & & $(\mathrm{R}-5)$ & R-2 & R-9 & R-9 & \\
\hline AK, CO, ME, MI, MN, ND, WI, WY & 17 & & & & & (R-5) & R-2 & R-9 & R-9 & \\
\hline
\end{tabular}


Table A.2 Basement and Crawl Space Insulation R-Values for Detached One- and Two-Family Dwellings

\begin{tabular}{|c|c|c|c|c|c|c|c|}
\hline \multirow[t]{3}{*}{ Table A.2.1 } & \multirow[t]{3}{*}{ Climate Zone } & \multicolumn{3}{|c|}{ Basement Wall } & \multicolumn{3}{|c|}{ Crawl Space Wall } \\
\hline & & \multicolumn{6}{|c|}{ Window to Wall Area Ratio } \\
\hline & & $15 \%$ & $20 \%$ & $25 \%$ & $15 \%$ & $20 \%$ & $25 \%$ \\
\hline \multirow[t]{7}{*}{2003 IECC } & 1 & $\mathrm{R}-0$ & R-0 & $\mathrm{R}-0$ & $\mathrm{R}-0$ & $\mathrm{R}-0$ & R-0 \\
\hline & 2 & $\mathrm{R}-0$ & $\mathrm{R}-0$ & $\mathrm{R}-0$ & R-4 & R-4 & R-4 \\
\hline & 3 & $\mathrm{R}-0$ & $\mathrm{R}-0$ & $\mathrm{R}-0$ & R-5 & R-5 & R-5 \\
\hline & 4 & R-5 & R-5 & R-6 & R-5 & R-5 & $\mathrm{R}-6$ \\
\hline & 5 & R-5 & R-5 & R-8 & R-6 & R-6 & R-10 \\
\hline & 6 & R-6 & $\mathrm{R}-6$ & $\mathrm{R}-6$ & R-7 & R-7 & $\mathrm{R}-7$ \\
\hline & 7 & R-7 & R-7 & $\mathrm{R}-7$ & R-8 & R-9 & $R-9$ \\
\hline \multirow[t]{2}{*}{2006 IECC } & 1 & \multirow{2}{*}{\multicolumn{3}{|c|}{$\mathrm{R}-0$}} & \multirow{2}{*}{\multicolumn{3}{|c|}{$\mathrm{R}-0$}} \\
\hline & 2 & & & & & & \\
\hline
\end{tabular}

Difference between 2003 and 2006 IECC - Increased stringency in bold Black, decreased stringency in bold (Red), and no change in stringency is blank.

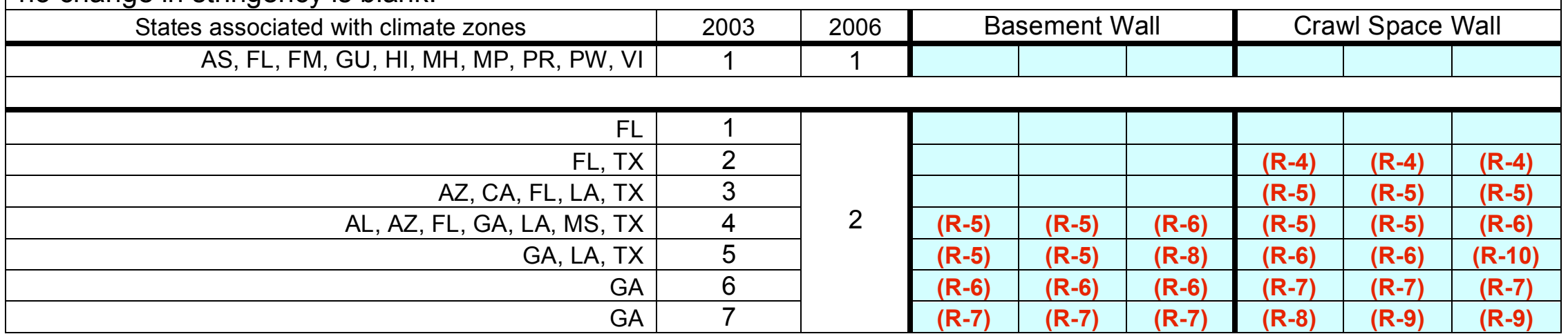




\begin{tabular}{|c|c|c|c|c|c|c|c|c|}
\hline \multirow[t]{3}{*}{ Table A.2.2 } & \multirow{3}{*}{\multicolumn{2}{|c|}{ Climate Zone }} & \multicolumn{3}{|c|}{ Basement Wall } & \multicolumn{3}{|c|}{ Crawl Space Wall } \\
\hline & & & \multicolumn{6}{|c|}{ Window to Wall Area Ratio } \\
\hline & & & $15 \%$ & $20 \%$ & $25 \%$ & $15 \%$ & $20 \%$ & $25 \%$ \\
\hline \multirow{8}{*}{2003 IECC } & \multicolumn{2}{|c|}{3} & R-0 & $\mathrm{R}-0$ & $\mathrm{R}-0$ & $\mathrm{R}-5$ & $\mathrm{R}-5$ & $\mathrm{R}-5$ \\
\hline & \multicolumn{2}{|c|}{4} & $\mathrm{R}-5$ & $\mathrm{R}-5$ & R-6 & $\mathrm{R}-5$ & $\mathrm{R}-5$ & $\mathrm{R}-6$ \\
\hline & \multicolumn{2}{|c|}{5} & $\mathrm{R}-5$ & R-5 & R-8 & $\mathrm{R}-6$ & $\mathrm{R}-6$ & $\mathrm{R}-10$ \\
\hline & \multicolumn{2}{|c|}{6} & R-6 & R-6 & R-6 & R-7 & R-7 & R-7 \\
\hline & \multicolumn{2}{|c|}{7} & R-7 & R-7 & R-7 & R-8 & R-9 & R-9 \\
\hline & \multicolumn{2}{|c|}{8} & R-8 & $\mathrm{R}-8$ & R-8 & $\mathrm{R}-10$ & $\mathrm{R}-10$ & R-10 \\
\hline & \multicolumn{2}{|c|}{9} & $\mathrm{R}-8$ & $\mathrm{R}-9$ & R-9 & $\mathrm{R}-11$ & $\mathrm{R}-13$ & $\mathrm{R}-13$ \\
\hline & \multicolumn{2}{|c|}{$\frac{10}{3}$} & R-9 & R-9 & R-9 & $\mathrm{R}-17$ & $\mathrm{R}-16$ & $\mathrm{R}-17$ \\
\hline 2006 IECC & & & \multicolumn{3}{|c|}{$\mathrm{R}-0$} & \multicolumn{3}{|c|}{ R-5 } \\
\hline \multicolumn{9}{|c|}{$\begin{array}{l}\text { Difference between } 2003 \text { and } 2006 \text { IECC - Increased stringency in bold Black, decreased stringency in bold (Red), and } \\
\text { no change in stringency is blank. }\end{array}$} \\
\hline States associated with climate zones & 2003 & 2006 & \multicolumn{3}{|c|}{ Basement Wall } & \multicolumn{3}{|c|}{ Crawl Space Wall } \\
\hline $\mathrm{AZ}, \mathrm{CA}$ & 3 & \multirow{8}{*}{3} & & & & & & \\
\hline $\mathrm{AL}, \mathrm{AZ}, \mathrm{CA}, \mathrm{MS}$ & 4 & & $(\mathrm{R}-5)$ & $(\mathrm{R}-5)$ & $(\mathrm{R}-6)$ & & & $(\mathrm{R}-1)$ \\
\hline AL, CA, GA, LA, MS, NV, SC, TX & 5 & & $(\mathrm{R}-5)$ & $(\mathrm{R}-5)$ & $(\mathrm{R}-8)$ & $(\mathrm{R}-1)$ & $(\mathrm{R}-1)$ & (R-5) \\
\hline $\mathrm{AL}, \mathrm{AZ}, \mathrm{AR}, \mathrm{CA}, \mathrm{GA}, \mathrm{LA}, \mathrm{MS}, \mathrm{NC}, \mathrm{OK}, \mathrm{SC}, \mathrm{TX}$ & 6 & & $(\mathrm{R}-6)$ & $(\mathrm{R}-6)$ & $(\mathrm{R}-6)$ & (R-2) & (R-2) & $(\mathrm{R}-2)$ \\
\hline AL, AZ, AR, GA, MS, NM, NC, OK, SC, TN, TX & 7 & & $(\mathrm{R}-7)$ & $(\mathrm{R}-7)$ & $(\mathrm{R}-7)$ & $(\mathrm{R}-3)$ & $(\mathrm{R}-4)$ & $(\mathrm{R}-4)$ \\
\hline AL, AR, CA, GA, NC, OK, TN & 8 & & (R-8) & (R-8) & $(\mathrm{R}-8)$ & $(\mathrm{R}-5)$ & (R-5) & (R-5) \\
\hline OK, TN, TX & 9 & & $(\mathrm{R}-8)$ & $(\mathrm{R}-9)$ & $(\mathrm{R}-9)$ & $(\mathrm{R}-6)$ & $(\mathrm{R}-8)$ & $(\mathrm{R}-8)$ \\
\hline UT & 10 & & (R-9) & (R-9) & (R-9) & $(\mathrm{R}-12)$ & $(\mathrm{R}-11)$ & (R-12) \\
\hline
\end{tabular}




\begin{tabular}{|c|c|c|c|c|c|c|c|}
\hline \multirow[t]{3}{*}{ Table A.2.3 } & \multirow[t]{3}{*}{ Climate Zone } & \multicolumn{3}{|c|}{ Basement Wall } & \multicolumn{3}{|c|}{ Crawl Space Wall } \\
\hline & & \multicolumn{6}{|c|}{ Window to Wall Area Ratio } \\
\hline & & $15 \%$ & $20 \%$ & $25 \%$ & $15 \%$ & $20 \%$ & $25 \%$ \\
\hline \multirow[t]{7}{*}{2003 IECC } & 5 & R-5 & R-5 & R-8 & R-6 & R-6 & $\mathrm{R}-10$ \\
\hline & 7 & R-7 & R-7 & R-7 & R-8 & R-9 & $R-9$ \\
\hline & 8 & R-8 & $\mathrm{R}-8$ & R-8 & $\mathrm{R}-10$ & R-10 & $\mathrm{R}-10$ \\
\hline & 9 & R-8 & R-9 & R-9 & $\mathrm{R}-11$ & $\mathrm{R}-13$ & $\mathrm{R}-13$ \\
\hline & 10 & R-9 & R-9 & R-9 & $\mathrm{R}-17$ & $\mathrm{R}-16$ & $\mathrm{R}-17$ \\
\hline & 11 & R-9 & R-9 & R-9 & $\mathrm{R}-17$ & R-16 & $\mathrm{R}-17$ \\
\hline & 12 & R-10 & R-10 & R-10 & $R-19$ & R-17 & R-22 \\
\hline \multirow[t]{2}{*}{2006 IECC } & 4 & \multirow{2}{*}{\multicolumn{3}{|c|}{$\mathrm{R}-13$}} & \multirow{2}{*}{\multicolumn{3}{|c|}{ R-13 }} \\
\hline & 4 Marine & & & & & & \\
\hline
\end{tabular}

Difference between 2003 and 2006 IECC - Increased stringency in bold Black, decreased stringency in bold (Red), and no change in stringency is blank.

\begin{tabular}{|c|c|c|c|c|c|c|c|c|}
\hline \multirow[t]{2}{*}{ States associated with climate zones } & \multirow{2}{*}{$\frac{2003}{5}$} & \multirow[t]{2}{*}{2006} & \multicolumn{3}{|c|}{ Basement Wall } & \multicolumn{3}{|c|}{ Crawl Space Wall } \\
\hline & & & $\mathbf{R}-\mathbf{8}$ & R-8 & R-5 & $\mathbf{R - 7}$ & R-7 & $\mathbf{R}-3$ \\
\hline GA, NC & 7 & \multirow{6}{*}{4} & R-6 & R-6 & R-6 & $\mathbf{R}-\mathbf{5}$ & R-4 & $\mathbf{R}-4$ \\
\hline AZ, AR, CA, GA, NM, NC, TN, TX, VA & 8 & & R-5 & R-5 & R-5 & $\mathbf{R}-\mathbf{3}$ & $\mathbf{R}-\mathbf{3}$ & $\mathbf{R}-\mathbf{3}$ \\
\hline AR, CA, DE, KA, KY, MD, MO, NM, NC, TN, TX, VA & 9 & & R-5 & R-4 & R-4 & R-2 & & \\
\hline $\begin{array}{r}\text { AZ, DE, DC, IL, IN, KA, KY, MD, MO, NJ, NM, NY, OK, } \\
\text { PA, TN, VA, WV }\end{array}$ & 10 & & $\mathbf{R}-\mathbf{4}$ & R-4 & $\mathbf{R}-\mathbf{4}$ & $(\mathrm{R}-4)$ & (R-3) & $(\mathrm{R}-4)$ \\
\hline $\begin{array}{r}\mathrm{CO}, \mathrm{IL}, \mathrm{IN}, \mathrm{KA}, \mathrm{KY}, \mathrm{MD}, \mathrm{MO}, \mathrm{NJ}, \mathrm{NM}, \mathrm{NY}, \mathrm{OH}, \mathrm{PA}, \mathrm{VA}, \\
\text { WV }\end{array}$ & 11 & & $\mathbf{R}-\mathbf{4}$ & R-4 & $\mathbf{R}-\mathbf{4}$ & $(\mathrm{R}-4)$ & $(\mathrm{R}-3)$ & $(\mathrm{R}-4)$ \\
\hline MD, MO, NM, NY & 12 & & R-3 & R-3 & R-3 & $(\mathrm{R}-6)$ & (R-4) & $(\mathrm{R}-9)$ \\
\hline $\mathrm{CA}, \mathrm{OR}$ & 9 & \multirow{4}{*}{ 4-M } & R-5 & R-4 & R-4 & R-2 & & \\
\hline OR, WA & 10 & & $R-4$ & R-4 & $R-4$ & (R-4) & $(\mathrm{R}-3)$ & $(\mathrm{R}-4)$ \\
\hline OR, WA & 11 & & $\mathrm{R}-4$ & R-4 & $R-4$ & (R-4) & (R-3) & $(R-4)$ \\
\hline WA & 12 & & R-3 & R-3 & $R-3$ & (R-6) & (R-4) & $(R-9)$ \\
\hline
\end{tabular}




\begin{tabular}{|c|c|c|c|c|c|c|c|}
\hline \multirow[t]{3}{*}{ Table A.2.4 } & \multirow[t]{3}{*}{ Climate Zone } & \multicolumn{3}{|c|}{ Basement Wall } & \multicolumn{3}{|c|}{ Crawl Space Wall } \\
\hline & & \multicolumn{6}{|c|}{ Window to Wall Area Ratio } \\
\hline & & $15 \%$ & $20 \%$ & $25 \%$ & $15 \%$ & $20 \%$ & $25 \%$ \\
\hline \multirow[t]{6}{*}{2003 IECC } & 10 & $\mathrm{R}-9$ & $\mathrm{R}-9$ & R-9 & R-17 & $\mathrm{R}-16$ & $\mathrm{R}-17$ \\
\hline & 11 & $\mathrm{R}-9$ & R-9 & R-9 & R-17 & $\mathrm{R}-16$ & R-17 \\
\hline & 12 & $\mathrm{R}-10$ & R-10 & R-10 & R-19 & $\mathrm{R}-17$ & R-22 \\
\hline & 13 & $\mathrm{R}-10$ & R-10 & R-10 & R-20 & $\mathrm{R}-17$ & R-20 \\
\hline & 14 & $\mathrm{R}-11$ & $\mathrm{R}-11$ & $\mathrm{R}-14$ & $\mathrm{R}-20$ & $\mathrm{R}-17$ & $\mathrm{n} / \mathrm{a}$ \\
\hline & 15 & R-11 & R-11 & R-15 & R-20 & R-19 & $\mathrm{n} / \mathrm{a}$ \\
\hline 2006 IECC & 5 & \multicolumn{3}{|c|}{$R-13$} & \multicolumn{3}{|c|}{$R-13$} \\
\hline
\end{tabular}

Difference between 2003 and 2006 IECC - Increased stringency in bold Black, decreased stringency in bold (Red), and no change in stringency is blank.

\begin{tabular}{|c|c|c|c|c|c|c|c|c|}
\hline States associated with climate zones & \multirow{2}{*}{$\frac{2003}{10}$} & \multirow[t]{2}{*}{2006} & \multicolumn{3}{|c|}{ Basement Wall } & \multicolumn{3}{|c|}{ Crawl Space Wall } \\
\hline AZ, IL, MD, UT & & & R-4 & $\mathrm{R}-4$ & R-4 & $(\mathrm{R}-4)$ & $(\mathrm{R}-3)$ & $(\mathrm{R}-4)$ \\
\hline $\mathrm{CA}, \mathrm{CO}, \mathrm{IL}, \mathrm{IN}, \mathrm{KA}, \mathrm{NJ}, \mathrm{NM}, \mathrm{NC}, \mathrm{OH}, \mathrm{PA}, \mathrm{WA}, \mathrm{WV}$ & 11 & \multirow{5}{*}{5} & R-4 & R-4 & R-4 & $(\mathrm{R}-4)$ & (R-3) & $(\mathrm{R}-4)$ \\
\hline $\begin{array}{r}\text { CT, ID, IL, IN, KA, MA, MO, NV, NJ, NM, NY, OH, OR, PA, } \\
\text { RI, UT, WA, WV }\end{array}$ & 12 & & R-3 & R-3 & R-3 & $(\mathrm{R}-6)$ & $(\mathrm{R}-4)$ & $(\mathrm{R}-9)$ \\
\hline $\begin{array}{r}\text { AZ, CA, CO, CT, ID, IL, IN, IO, KA, MD, MA, MI, MO, NB, } \\
\text { NV, NJ, NM, NY, OH, OR, PA, UT, WV }\end{array}$ & 13 & & R-3 & R-3 & R-3 & $(\mathrm{R}-7)$ & $(\mathrm{R}-4)$ & (R-7) \\
\hline $\begin{array}{r}\text { AZ, CT, ID, IL, IN, IO, MA, MI, NB, NY, OH, OR, PA, RI, } \\
\text { SD, UT, WA, WY }\end{array}$ & 14 & & $\mathbf{R}-\mathbf{2}$ & $\mathbf{R}-\mathbf{2}$ & $(\mathrm{R}-1)$ & $(\mathrm{R}-7)$ & $(\mathrm{R}-4)$ & $\mathrm{n} / \mathrm{a}$ \\
\hline $\mathrm{CA}, \mathrm{CO}, \mathrm{ID}, \mathrm{IO}, \mathrm{MI}, \mathrm{NB}, \mathrm{NV}, \mathrm{NH}, \mathrm{NM}, \mathrm{NY}, \mathrm{OR}, \mathrm{PA}, \mathrm{WA}$ & 15 & & R-2 & R-2 & $(\mathrm{R}-2)$ & $(\mathrm{R}-7)$ & $(\mathrm{R}-6)$ & $\mathrm{n} / \mathbf{a}$ \\
\hline
\end{tabular}




\begin{tabular}{|c|c|c|c|c|c|c|c|c|}
\hline \multirow[t]{3}{*}{ Table A.2.5 } & \multirow{3}{*}{\multicolumn{2}{|c|}{ Climate Zone }} & \multicolumn{3}{|c|}{ Basement Wall } & \multicolumn{3}{|c|}{ Crawl Space Wall } \\
\hline & & & \multicolumn{6}{|c|}{ Window to Wall Area Ratio } \\
\hline & & & $15 \%$ & $20 \%$ & $25 \%$ & $15 \%$ & $20 \%$ & $25 \%$ \\
\hline \multirow{5}{*}{2003 IECC } & \multicolumn{2}{|c|}{12} & $R-10$ & $R-10$ & $R-10$ & R-19 & $\mathrm{R}-17$ & $\mathrm{R}-22$ \\
\hline & \multicolumn{2}{|c|}{14} & $\mathrm{R}-11$ & $\mathrm{R}-11$ & R-14 & R-20 & $\mathrm{R}-17$ & $\mathrm{n} / \mathrm{a}$ \\
\hline & \multicolumn{2}{|c|}{15} & $\mathrm{R}-11$ & $\mathrm{R}-11$ & $\mathrm{R}-15$ & R-20 & R-19 & $\mathrm{n} / \mathrm{a}$ \\
\hline & \multicolumn{2}{|c|}{16} & $R-18$ & R-19 & R-28 & R-20 & $R-19$ & $\mathrm{n} / \mathrm{a}$ \\
\hline & \multicolumn{2}{|c|}{17} & R-19 & R-19 & $\mathrm{R}-28$ & R-20 & R-19 & $\mathrm{n} / \mathrm{a}$ \\
\hline 2006 IECC & \multicolumn{2}{|c|}{$\frac{6}{7 \& 8}$} & \multicolumn{3}{|c|}{$\mathrm{R}-13$} & \multicolumn{3}{|c|}{$\mathrm{R}-13$} \\
\hline \multicolumn{9}{|c|}{$\begin{array}{l}\text { Difference between } 2003 \text { and } 2006 \text { IECC - Increased stringency in bold Black, decreased stringency in bold (Red), and } \\
\text { no change in stringency is blank. }\end{array}$} \\
\hline States associated with climate zones & 2003 & 2006 & \multicolumn{3}{|c|}{ Basement Wall } & \multicolumn{3}{|c|}{ Crawl Space Wall } \\
\hline UT & 12 & \multirow{5}{*}{6} & R-3 & $\mathbf{R}-\mathbf{3}$ & $\mathbf{R}-3$ & $(\mathrm{R}-6)$ & $(\mathrm{R}-4)$ & $(\mathrm{R}-9)$ \\
\hline $\begin{array}{rr}\mathrm{MI}, \mathrm{NY} \\
\end{array}$ & 14 & & $\mathbf{R - 2}$ & $\mathbf{R}-\mathbf{2}$ & $(\mathrm{R}-1)$ & (R-7) & $(\mathrm{R}-4)$ & $\mathrm{n} / \mathrm{a}$ \\
\hline $\begin{array}{r}\mathrm{CA}, \mathrm{CO}, \mathrm{ID}, \mathrm{IO}, \mathrm{ME}, \mathrm{MI}, \mathrm{MN}, \mathrm{MT}, \mathrm{NH}, \mathrm{NY}, \mathrm{PA}, \mathrm{SD}, \mathrm{VT}, \\
\text { WA, WI, WY }\end{array}$ & 15 & & R-2 & R-2 & (R-2) & (R-7) & (R-6) & $\mathrm{n} / \mathrm{a}$ \\
\hline $\mathrm{CO}, \mathrm{ID}, \mathrm{ME}, \mathrm{MI}, \mathrm{MN}, \mathrm{MT}, \mathrm{NH}, \mathrm{NY}, \mathrm{ND}, \mathrm{SD}, \mathrm{VT}, \mathrm{WI}, \mathrm{WY}$ & 16 & & $(\mathrm{R}-5)$ & $(\mathrm{R}-6)$ & $(\mathrm{R}-15)$ & $(\mathrm{R}-7)$ & $(\mathrm{R}-6)$ & $\mathrm{n} / \mathrm{a}$ \\
\hline ME, MN & 17 & & $(\mathrm{R}-6)$ & $(\mathrm{R}-6)$ & $(\mathrm{R}-15)$ & $(\mathrm{R}-7)$ & $(\mathrm{R}-6)$ & $\mathrm{n} / \mathrm{a}$ \\
\hline AK, MI, MN & 16 & \multirow{2}{*}{$7 \& 8$} & $(\mathrm{R}-5)$ & $(\mathrm{R}-6)$ & $(\mathrm{R}-15)$ & $(\mathrm{R}-7)$ & $(\mathrm{R}-6)$ & $\mathrm{n} / \mathrm{a}$ \\
\hline $\mathrm{AK}, \mathrm{CO}, \mathrm{ME}, \mathrm{MI}, \mathrm{MN}, \mathrm{ND}, \mathrm{WI}, \mathrm{WY}$ & 17 & & $(\mathrm{R}-6)$ & $(\mathrm{R}-6)$ & $(\mathrm{R}-15)$ & $(\mathrm{R}-7)$ & $(\mathrm{R}-6)$ & $\mathrm{n} / \mathrm{a}$ \\
\hline
\end{tabular}


Table A.3 Slab Insulation R-Values for One- and Two-Family Dwellings

\begin{tabular}{|c|c|c|c|c|c|c|c|c|c|c|c|c|c|c|}
\hline \multirow[t]{3}{*}{ Table A.3.1 } & \multirow{3}{*}{\multicolumn{2}{|c|}{ Climate Zone }} & Unhe & ated Sl & Perim & eter $\mathrm{F}$ & alue, & epth & Hea & ed Sla & Derime & ter R- & ue, De & \\
\hline & & & \multicolumn{12}{|c|}{ Window to Wall Area Ratio } \\
\hline & & & \multicolumn{2}{|c|}{$15 \%$} & \multicolumn{2}{|c|}{$20 \%$} & \multicolumn{2}{|c|}{$25 \%$} & \multicolumn{2}{|c|}{$15 \%$} & \multicolumn{2}{|c|}{$20 \%$} & \multicolumn{2}{|c|}{$25 \%$} \\
\hline \multirow{7}{*}{2003 IECC } & \multicolumn{2}{|c|}{1} & $\mathrm{R}-0$ & $0 \mathrm{ft}$. & $\mathrm{R}-0$ & $0 \mathrm{ft}$. & $\mathrm{R}-\mathrm{0}$, & $0 \mathrm{ft}$. & $\mathrm{R}-2$ & $2 \mathrm{ft}$. & R-2, & $2 \mathrm{ft}$. & $\mathrm{R}-2$ & $2 \mathrm{ft}$. \\
\hline & \multicolumn{2}{|c|}{2} & R-0, & $0 \mathrm{ft}$. & R-0, & $0 \mathrm{ft}$. & R-0, & $0 \mathrm{ft}$. & R-2, & $2 \mathrm{ft}$. & R-2, & $2 \mathrm{ft}$. & R-2, & $2 \mathrm{ft}$. \\
\hline & \multicolumn{2}{|c|}{3} & R-0, & $0 \mathrm{ft}$. & R-0, & $0 \mathrm{ft}$. & $\mathrm{R}-0$, & $0 \mathrm{ft}$. & R-2, & $2 \mathrm{ft}$. & $\mathrm{R}-2$, & $2 \mathrm{ft}$. & $\mathrm{R}-2$, & $2 \mathrm{ft}$. \\
\hline & \multicolumn{2}{|c|}{4} & R-0, & $0 \mathrm{ft}$. & R-0, & $0 \mathrm{ft}$. & R-0, & $0 \mathrm{ft}$. & R-2, & $2 \mathrm{ft}$. & $\mathrm{R}-2$, & $2 \mathrm{ft}$. & R-2, & $2 \mathrm{ft}$. \\
\hline & \multicolumn{2}{|c|}{5} & R-0, & $0 \mathrm{ft}$. & R-0, & $0 \mathrm{ft}$. & R-0, & $0 \mathrm{ft}$. & R-2, & $2 \mathrm{ft}$ & R-2, & $2 \mathrm{ft}$. & R-2, & $2 \mathrm{ft}$. \\
\hline & \multicolumn{2}{|c|}{6} & R-4, & $2 \mathrm{ft}$. & R-0, & $0 \mathrm{ft}$. & R-0, & $0 \mathrm{ft}$. & R-6, & $2 \mathrm{ft}$. & R-2, & $2 \mathrm{ft}$. & $\mathrm{R}-2$, & $2 \mathrm{ft}$. \\
\hline & \multicolumn{2}{|c|}{7} & R-4, & $2 \mathrm{ft}$. & $\mathrm{R}-0$ & $0 \mathrm{ft}$. & R-0, & $0 \mathrm{ft}$. & R-6, & $2 \mathrm{ft}$. & $\mathrm{R}-2$, & $2 \mathrm{ft}$. & $\mathrm{R}-2$, & $2 \mathrm{ft}$. \\
\hline \multirow[t]{2}{*}{2006 IECC } & \multirow{2}{*}{\multicolumn{2}{|c|}{$\frac{1}{2}$}} & \multirow{2}{*}{\multicolumn{6}{|c|}{$\mathrm{R}-0,0 \mathrm{ft}$. }} & \multicolumn{6}{|c|}{$\mathrm{R}-5,0 \mathrm{ft}$} \\
\hline & & & & & & & & & \multicolumn{6}{|c|}{$\mathrm{R}-5,2 \mathrm{ft}}$. \\
\hline \multicolumn{15}{|c|}{$\begin{array}{l}\text { Difference between } 2003 \text { and } 2006 \text { IECC - Increased stringency in bold Black, decreased stringency in bold (Red), and } \\
\text { no change in stringency is blank. }\end{array}$} \\
\hline $\begin{array}{l}\text { States associated with } \\
\text { climate zones }\end{array}$ & 2003 & 2006 & \multicolumn{6}{|c|}{ Unheated Slab Perimeter R-Value, Depth } & \multicolumn{6}{|c|}{ Heated Slab Perimeter R-Value, Depth } \\
\hline $\begin{array}{r}\text { AS, FL, FM, GU, HI, MH, MP, } \\
\text { PR, PW, VI }\end{array}$ & 1 & 1 & & & & & & & R-3, & & R-3, & & R-3, & \\
\hline $\mathrm{FL}$ & 1 & \multirow{7}{*}{2} & & & & & & & $R-3$ & & R-3 & & R-3 & \\
\hline FL, TX & 2 & & & & & & & & R-3, & & R-3, & & R-3, & \\
\hline $\mathrm{AZ}, \mathrm{CA}, \mathrm{FL}, \mathrm{LA}, \mathrm{TX}$ & 3 & & & & & & & & R-3, & & R-3, & & R-3, & \\
\hline $\mathrm{AL}, \mathrm{AZ}, \mathrm{FL}, \mathrm{GA}, \mathrm{LA}, \mathrm{MS}, \mathrm{TX}$ & 4 & & & & & & & & R-3, & & R-3, & & R-3, & \\
\hline GA, LA, TX & 5 & & & & & & & & R-3, & & R-3, & & R-3, & \\
\hline GA & 6 & & $(\mathrm{R}-4)$, & (2 ft.) & & & & & (R-1), & & R-3, & & R-3, & \\
\hline GA & 7 & & $(\mathrm{R}-4)$, & (2 ft.) & & & & & $(\mathrm{R}-1)$, & & R-3, & & R-3, & \\
\hline
\end{tabular}




\begin{tabular}{|c|c|c|c|c|c|c|c|c|c|c|c|c|c|}
\hline \multirow{3}{*}{ Table A.3.2 } & \multirow{3}{*}{ Climate Zone } & Unhe & ated & Perir & eter & alue, & epth & $\mathrm{Hea}$ & ed S & Perim & ter $\mathrm{R}$ & ue, D & \\
\hline & & \multicolumn{12}{|c|}{ Window to Wall Area Ratio } \\
\hline & & \multicolumn{2}{|c|}{$15 \%$} & \multicolumn{2}{|c|}{$20 \%$} & \multicolumn{2}{|c|}{$25 \%$} & \multicolumn{2}{|c|}{$15 \%$} & \multicolumn{2}{|c|}{$20 \%$} & \multicolumn{2}{|c|}{$25 \%$} \\
\hline \multirow[t]{8}{*}{2003 IECC } & 3 & $\mathrm{R}-0$, & $0 \mathrm{ft}$. & R-0, & $0 \mathrm{ft}$. & R-0, & $0 \mathrm{ft}$. & $\mathrm{R}-2$, & $2 \mathrm{ft}$. & $\mathrm{R}-2$, & $2 \mathrm{ft}$. & R-2, & $2 \mathrm{ft}$. \\
\hline & 4 & R-0, & $0 \mathrm{ft}$. & $\mathrm{R}-0$, & $0 \mathrm{ft}$. & R-0, & $0 \mathrm{ft}$. & $\mathrm{R}-2$, & $2 \mathrm{ft}$. & $\mathrm{R}-2$, & $2 \mathrm{ft}$. & $\mathrm{R}-2$, & $2 \mathrm{ft}$. \\
\hline & 5 & $\mathrm{R}-0$, & $0 \mathrm{ft}$. & $\mathrm{R}-0$, & $0 \mathrm{ft}$. & R-0, & $0 \mathrm{ft}$. & $\mathrm{R}-2$, & $2 \mathrm{ft}$. & $\mathrm{R}-2$, & $2 \mathrm{ft}$. & $\mathrm{R}-2$, & $2 \mathrm{ft}$. \\
\hline & 6 & R-4, & $2 \mathrm{ft}$. & R-0, & $0 \mathrm{ft}$. & R-0, & $0 \mathrm{ft}$. & $\mathrm{R}-6$, & $2 \mathrm{ft}$. & $\mathrm{R}-2$, & $2 \mathrm{ft}$. & R-2, & $2 \mathrm{ft}$. \\
\hline & 7 & R-4, & $2 \mathrm{ft}$. & $\mathrm{R}-0$, & $0 \mathrm{ft}$. & R-0, & $0 \mathrm{ft}$. & R-6, & $2 \mathrm{ft}$. & $\mathrm{R}-2$, & $2 \mathrm{ft}$. & R-2, & $2 \mathrm{ft}$. \\
\hline & 8 & R-5, & $2 \mathrm{ft}$. & R-6, & $2 \mathrm{ft}$. & R-6, & $2 \mathrm{ft}$. & R-7, & $2 \mathrm{ft}$. & $\mathrm{R}-8$, & $2 \mathrm{ft}$. & R-8, & $2 \mathrm{ft}$. \\
\hline & 9 & R-5, & $2 \mathrm{ft}$. & R-6, & $2 \mathrm{ft}$. & R-6, & $2 \mathrm{ft}$. & R-7, & $2 \mathrm{ft}$. & $\mathrm{R}-8$, & $2 \mathrm{ft}$. & $\mathrm{R}-8$, & $2 \mathrm{ft}$. \\
\hline & 10 & R-6, & $2 \mathrm{ft}$. & R-6, & $2 \mathrm{ft}$. & R-6, & $2 \mathrm{ft}$. & R-8, & $2 \mathrm{ft}$. & R-8, & $2 \mathrm{ft}$. & R-8, & $2 \mathrm{ft}$. \\
\hline 2006 IECC & 3 & \multicolumn{6}{|c|}{$\mathrm{R}-0,0 \mathrm{ft}}$. & \multicolumn{6}{|c|}{$\mathrm{R}-5,2 \mathrm{ft}$} \\
\hline
\end{tabular}

Difference between 2003 and 2006 IECC - Increased stringency in bold Black, decreased stringency in bold (Red), and no change in stringency is blank.

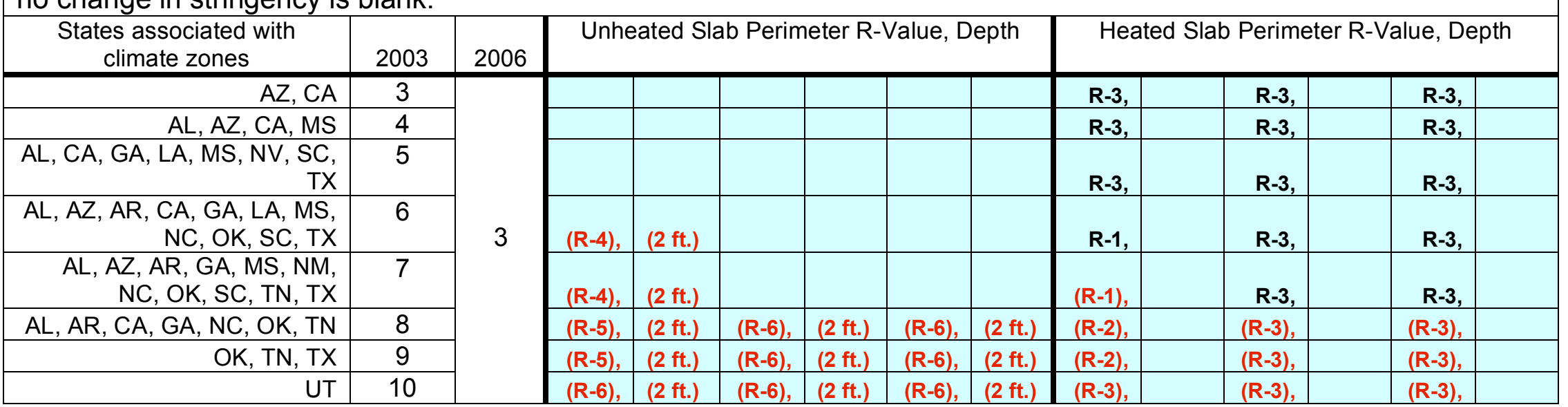




\begin{tabular}{|c|c|c|c|c|c|c|c|c|c|c|c|c|c|c|}
\hline \multirow{3}{*}{ Table A.3.3 } & \multirow{3}{*}{\multicolumn{2}{|c|}{ Climate Zone }} & Unhe & ated & b Perin & eter & Value, [ & epth & $\mathrm{Hea}$ & ted SI & Perim & ter $\mathrm{R}$ & alue, D & pth \\
\hline & & & \multicolumn{12}{|c|}{ Window to Wall Area Ratio } \\
\hline & & & \multicolumn{2}{|c|}{$15 \%$} & \multicolumn{2}{|c|}{$20 \%$} & \multicolumn{2}{|c|}{$25 \%$} & \multicolumn{2}{|c|}{$15 \%$} & \multicolumn{2}{|c|}{$20 \%$} & \multicolumn{2}{|c|}{$25 \%$} \\
\hline \multirow[t]{7}{*}{2003 IECC } & \multicolumn{2}{|c|}{5} & R-0, & $0 \mathrm{ft}$. & R-0, & $0 \mathrm{ft}$. & $\mathrm{R}-0$ & $0 \mathrm{ft}$. & $\mathrm{R}-2$, & $2 \mathrm{ft}$. & $\mathrm{R}-2$, & $2 \mathrm{ft}$. & $\mathrm{R}-2$, & $2 \mathrm{ft}$. \\
\hline & \multicolumn{2}{|c|}{7} & R-4, & $2 \mathrm{ft}$. & R-0, & $0 \mathrm{ft}$. & R-0, & $0 \mathrm{ft}$. & R-6, & $2 \mathrm{ft}$. & R-2, & $2 \mathrm{ft}$. & R-2, & $2 \mathrm{ft}$. \\
\hline & \multicolumn{2}{|c|}{8} & R-5, & $2 \mathrm{ft}$. & R-6, & $2 \mathrm{ft}$. & $\mathrm{R}-6$, & $2 \mathrm{ft}$. & R-7, & $2 \mathrm{ft}$. & $\mathrm{R}-8$, & $2 \mathrm{ft}$. & R-8, & $2 \mathrm{ft}$. \\
\hline & \multicolumn{2}{|c|}{9} & R-5, & $2 \mathrm{ft}$. & R-6, & $2 \mathrm{ft}$. & R-6, & $2 \mathrm{ft}$. & R-7, & $2 \mathrm{ft}$. & R-8, & $2 \mathrm{ft}$. & R-8, & $2 \mathrm{ft}$. \\
\hline & \multicolumn{2}{|c|}{10} & R-6, & $2 \mathrm{ft}$. & R-6, & $2 \mathrm{ft}$. & R-6, & $2 \mathrm{ft}$. & R-8, & $2 \mathrm{ft}$. & R-8, & $2 \mathrm{ft}$. & R-8, & $2 \mathrm{ft}$. \\
\hline & \multirow{2}{*}{\multicolumn{2}{|c|}{$\frac{11}{12}$}} & R-6, & $2 \mathrm{ft}$. & R-6, & $2 \mathrm{ft}$. & R-6, & $2 \mathrm{ft}$. & R-8, & $2 \mathrm{ft}$. & R-8, & $2 \mathrm{ft}$. & R-8, & $2 \mathrm{ft}$. \\
\hline & & & R-9, & $2 \mathrm{ft}$. & R-7, & $2 \mathrm{ft}$. & $\mathrm{n} / \mathrm{a}$ & & $R-11$ & $2 \mathrm{ft}$. & R-9, & $2 \mathrm{ft}$. & $\mathrm{n} / \mathrm{a}$ & \\
\hline 2006 IECC & \multicolumn{2}{|c|}{$\frac{4}{4 \text { Marine }}$} & \multicolumn{6}{|c|}{$\mathrm{R}-10,2 \mathrm{ft}}$. & \multicolumn{6}{|c|}{$\mathrm{R}-15,2 \mathrm{ft}}$. \\
\hline \multicolumn{15}{|c|}{$\begin{array}{l}\text { Difference between } 2003 \text { and } 2006 \text { IECC - Increased stringency in bold Black, decreased stringency in bold (Red), and } \\
\text { no change in stringency is blank. }\end{array}$} \\
\hline $\begin{array}{c}\text { States associated with climate } \\
\text { zones }\end{array}$ & 2003 & 2006 & \multicolumn{6}{|c|}{ Unheated Slab Perimeter R-Value, Depth } & \multicolumn{6}{|c|}{ Heated Slab Perimeter R-Value, Depth } \\
\hline GA & 5 & \multirow{7}{*}{4} & R-10, & & R-10, & & R-10, & & $R-13$, & & R-13, & & $R-13$, & \\
\hline $\mathrm{GA}, \mathrm{NC}$ & 7 & & R-6, & & R-10, & & R-10, & & R-9, & & R-13, & & R-13, & \\
\hline $\begin{array}{r}\mathrm{AZ}, \mathrm{AR}, \mathrm{CA}, \mathrm{GA}, \mathrm{NM}, \mathrm{NC}, \mathrm{TN}, \\
\mathrm{TX}, \mathrm{VA}\end{array}$ & 8 & & R-5, & & R-4, & & R-4, & & $\mathrm{R}-8$, & & R-7, & & R-7, & \\
\hline $\begin{array}{r}\text { AR, CA, DE, KA, KY, MD, MO, } \\
\text { NM, NC, TN, TX, VA }\end{array}$ & 9 & & R-5, & & R-4, & & R-4, & & R-8, & & R-7, & & R-7, & \\
\hline $\begin{array}{r}\text { AZ, DE, DC, IL, IN, KA, KY, } \\
\text { MD, MO, NJ, NM, NY, OK, PA, } \\
\text { TN, VA, WV }\end{array}$ & 10 & & R-4, & & R-4, & & R-4, & & R-7, & & R-7, & & R-7, & \\
\hline $\begin{array}{l}\text { CO, IL, IN, KA, KY, MD, MO, } \\
\text { NJ, NM, NY, OH, PA, VA, WV }\end{array}$ & 11 & & R-4, & & R-4, & & R-4, & & R-7, & & R-7, & & R-7, & \\
\hline $\mathrm{MD}, \mathrm{MO}, \mathrm{NM}, \mathrm{NY}$ & 12 & & R-1, & & R-3, & & n/a & & $\mathrm{R}-4$, & & R-6, & & n/a & \\
\hline CA, OR & 9 & \multirow{4}{*}{ 4-M } & R-5, & & $R-4$, & & R-4, & & $R-8$, & & R-7, & & R-7, & \\
\hline OR, WA & 10 & & R-4, & & R-4, & & R-4, & & R-7, & & R-7, & & R-7, & \\
\hline OR, WA & 11 & & R-4, & & R-4, & & R-4, & & R-7, & & R-7, & & R-7, & \\
\hline WA & 12 & & R-1, & & R-3, & & $\mathrm{n} / \mathrm{a}$ & & R-4, & & R-6, & & $\mathrm{n} / \mathrm{a}$ & \\
\hline
\end{tabular}




\begin{tabular}{|c|c|c|c|c|c|c|c|c|c|c|c|c|c|c|}
\hline \multirow[t]{3}{*}{ Table A.3.4 } & \multirow{3}{*}{\multicolumn{2}{|c|}{ Climate Zone }} & Unhe & ated $\mathrm{S}$ & o Perin & eter $\mathrm{R}$ & alue, $\mathrm{L}$ & epth & $\mathrm{Hea}$ & ted Sla & Perim & ter R- & alue, D & \\
\hline & & & \multicolumn{12}{|c|}{ Window to Wall Area Ratio } \\
\hline & & & \multicolumn{2}{|c|}{$15 \%$} & \multicolumn{2}{|c|}{$20 \%$} & \multicolumn{2}{|c|}{$25 \%$} & \multicolumn{2}{|c|}{$15 \%$} & \multicolumn{2}{|c|}{$20 \%$} & \multicolumn{2}{|c|}{$25 \%$} \\
\hline \multirow[t]{6}{*}{2003 IECC } & \multicolumn{2}{|c|}{10} & $\mathrm{R}-6$, & $2 \mathrm{ft}$. & R-6, & $2 \mathrm{ft}$. & R-6, & $2 \mathrm{ft}$. & R-8, & $2 \mathrm{ft}$. & $\mathrm{R}-8$, & $2 \mathrm{ft}$. & $\mathrm{R}-8$, & $2 \mathrm{ft}$. \\
\hline & \multicolumn{2}{|c|}{11} & R-6, & $2 \mathrm{ft}$. & $\mathrm{R}-6$, & $2 \mathrm{ft}$. & R-6, & $2 \mathrm{ft}$. & R-8, & $2 \mathrm{ft}$. & R-8, & $2 \mathrm{ft}$. & $\mathrm{R}-8$, & $2 \mathrm{ft}$. \\
\hline & \multicolumn{2}{|c|}{12} & $\mathrm{R}-9$, & $2 \mathrm{ft}$. & R-7, & $2 \mathrm{ft}$. & $\mathrm{n} / \mathrm{a}$ & & $\mathrm{R}-11$, & $2 \mathrm{ft}$. & R-9, & $2 \mathrm{ft}$. & $\mathrm{n} / \mathrm{a}$ & \\
\hline & \multicolumn{2}{|c|}{13} & R-9, & $4 \mathrm{ft}$. & R-7, & $4 \mathrm{ft}$. & R-9, & $4 \mathrm{ft}$. & $\mathrm{R}-11$, & $4 \mathrm{ft}$. & R-9, & $4 \mathrm{ft}$. & R-11, & $4 \mathrm{ft}$. \\
\hline & \multicolumn{2}{|c|}{14} & $\mathrm{R}-11$, & $4 \mathrm{ft}$. & R-10, & $4 \mathrm{ft}$. & $\mathrm{n} / \mathrm{a}$ & & $\mathrm{R}-13$, & $4 \mathrm{ft}$. & R-12, & $4 \mathrm{ft}$. & $\mathrm{n} / \mathrm{a}$ & \\
\hline & \multirow{2}{*}{\multicolumn{2}{|c|}{$\begin{array}{cl}15 \\
5\end{array}$}} & R-13, & $4 \mathrm{ft}$. & R-12, & $4 \mathrm{ft}$. & $n / a$ & & $\mathrm{R}-15$, & $4 \mathrm{ft}$. & R-14, & $4 \mathrm{ft}$. & $\mathrm{n} / \mathrm{a}$ & \\
\hline 2006 IECC & & & \multicolumn{6}{|c|}{$\mathrm{R}-10,2 \mathrm{ft}$} & \multicolumn{6}{|c|}{$\mathrm{R}-15,2 \mathrm{ft}}$. \\
\hline \multicolumn{15}{|c|}{$\begin{array}{l}\text { Difference between } 2003 \text { and } 2006 \text { IECC - Increased stringency in bold Black, decreased stringency in bold (Red), and } \\
\text { no change in stringency is blank. }\end{array}$} \\
\hline $\begin{array}{l}\text { States associated with } \\
\text { climate zones }\end{array}$ & 2003 & 2006 & \multicolumn{6}{|c|}{ Unheated Slab Perimeter R-Value, Depth } & \multicolumn{6}{|c|}{ Heated Slab Perimeter R-Value, Depth } \\
\hline AZ, IL, MD, UT & 10 & \multirow{6}{*}{5} & $\mathrm{R}-4$, & & $R-4$, & & R-4, & & R-7, & & R-7, & & R-7, & \\
\hline $\begin{array}{r}\mathrm{CA}, \mathrm{CO}, \mathrm{IL}, \mathrm{IN}, \mathrm{KA}, \mathrm{NJ}, \mathrm{NM}, \\
\mathrm{NC}, \mathrm{OH}, \mathrm{PA}, \mathrm{WA}, \mathrm{WV}\end{array}$ & 11 & & $\mathrm{R}-4$, & & $\mathrm{R}-4$, & & R-4, & & R-7, & & R-7, & & R-7, & \\
\hline $\begin{array}{r}\text { CT, ID, IL, IN, KA, MA, MO, } \\
\text { NV, NJ, NM, NY, OH, OR, } \\
\text { PA, RI, UT, WA, WV }\end{array}$ & 12 & & R-1, & & R-3, & & $\mathrm{n} / \mathrm{a}$ & & R-4, & & R-6, & & $n / a$ & \\
\hline $\begin{array}{r}\text { AZ, CA, CO, CT, ID, IL, IN, } \\
\text { IO, KA, MD, MA, MI, MO, NB, } \\
\text { NV, NJ, NM, NY, OH, OR, } \\
\text { PA, UT, WV }\end{array}$ & 13 & & R-1, & (2 ft.) & R-3, & $(2 \mathrm{ft})$. & $\mathrm{R}-1$, & (2 ft.) & $\mathrm{R}-4$, & (2 ft.) & R-6, & $(2 \mathrm{ft})$. & $\mathrm{R}-4$, & $(2 \mathrm{ft})$. \\
\hline $\begin{array}{r}\text { AZ, CT, ID, IL, IN, IO, MA, MI, } \\
\text { NB, NY, OH, OR, PA, RI, SD, } \\
\text { UT, WA, WY }\end{array}$ & 14 & & (R-1), & (2 ft.) & & (2 ft.) & $n / a$ & & R-2, & (2 ft.) & R-3, & (2 ft.) & $n / a$ & \\
\hline $\begin{array}{r}\text { CA, CO, ID, IO, MI, NB, NV, } \\
\text { NH, NM, NY, OR, PA, WA }\end{array}$ & 15 & & (R-3), & $(2 \mathrm{ft})$. & (R-2), & (2 ft.) & n/a & & & (2 ft.) & $\mathrm{R}-1$, & (2 ft.) & $n / a$ & \\
\hline
\end{tabular}




\begin{tabular}{|c|c|c|c|c|c|c|c|c|c|c|c|c|c|}
\hline \multirow[t]{3}{*}{ Table A.3.5 } & \multirow{3}{*}{\multicolumn{2}{|c|}{ Climate Zone }} & Unhe & ated & b Perir & eter & Value & Hea & ted $S$ & Perime & $\operatorname{ter} \mathrm{R}$ & alue & epth \\
\hline & & & \multicolumn{11}{|c|}{ Window to Wall Area Ratio } \\
\hline & & & \multicolumn{2}{|c|}{$15 \%$} & \multicolumn{2}{|c|}{$20 \%$} & $25 \%$ & \multicolumn{2}{|c|}{$15 \%$} & \multicolumn{2}{|c|}{$20 \%$} & \multicolumn{2}{|c|}{$25 \%$} \\
\hline \multirow[t]{5}{*}{2003 IECC } & \multicolumn{2}{|c|}{12} & $\mathrm{R}-9$ & $2 \mathrm{ft}$. & $\mathrm{R}-7$, & $2 \mathrm{ft}$. & n/a & $\mathrm{R}-11$ & $2 \mathrm{ft}$. & $\mathrm{R}-9$ & $2 \mathrm{ft}$. & $\mathrm{n} / \mathrm{a}$ & \\
\hline & \multicolumn{2}{|c|}{14} & R-11, & $4 \mathrm{ft}$. & $\mathrm{R}-10$, & $4 \mathrm{ft}$. & $\mathrm{n} / \mathrm{a}$ & $\mathrm{R}-13$, & $4 \mathrm{ft}$. & $\mathrm{R}-12$, & $4 \mathrm{ft}$. & $\mathrm{n} / \mathrm{a}$ & \\
\hline & \multicolumn{2}{|c|}{15} & $\mathrm{R}-13$, & $4 \mathrm{ft}$. & $\mathrm{R}-12$, & $4 \mathrm{ft}$. & n/a & $\mathrm{R}-15$, & $4 \mathrm{ft}$. & $\mathrm{R}-14$, & $4 \mathrm{ft}$. & $\mathrm{n} / \mathrm{a}$ & \\
\hline & \multicolumn{2}{|c|}{16} & R-14, & $4 \mathrm{ft}$. & $\mathrm{R}-12$, & $4 \mathrm{ft}$. & $\mathrm{n} / \mathrm{a}$ & R-16, & $4 \mathrm{ft}$. & $\mathrm{R}-14$ & $4 \mathrm{ft}$. & $\mathrm{n} / \mathrm{a}$ & \\
\hline & \multicolumn{2}{|c|}{17} & $\mathrm{R}-18$, & $4 \mathrm{ft}$. & $\mathrm{R}-16$ & $4 \mathrm{ft}$. & n/a & $\mathrm{R}-20$, & $4 \mathrm{ft}$. & R-18, & $4 \mathrm{ft}$. & $\mathrm{n} / \mathrm{a}$ & \\
\hline 2006 IECC & \multicolumn{2}{|c|}{$\frac{6}{7 \& 8}$} & \multicolumn{5}{|c|}{$\mathrm{R}-10,4 \mathrm{ft}}$. & \multicolumn{6}{|c|}{$\mathrm{R}-15,4 \mathrm{ft}$} \\
\hline \multicolumn{14}{|c|}{$\begin{array}{l}\text { Difference between } 2003 \text { and } 2006 \text { IECC - Increased stringency in bold Black, decreased stringency in bold (Red), and } \\
\text { no change in stringency is blank. }\end{array}$} \\
\hline $\begin{array}{l}\begin{array}{l}\text { States associated with climate } \\
\text { zones }\end{array} \\
\text {. }\end{array}$ & 2003 & 2006 & \multicolumn{5}{|c|}{ Unheated Slab Perimeter R-Value, Depth } & \multicolumn{6}{|c|}{ Heated Slab Perimeter R-Value, Depth } \\
\hline UT & 12 & \multirow{5}{*}{6} & $\mathrm{R}-1$, & & R-3, & & $\mathrm{n} / \mathbf{a}$ & $\mathrm{R}-4$, & & R-6, & & n/a & \\
\hline MI, NY & 14 & & $(R-1)$, & & & & $\mathrm{n} / \mathrm{a}$ & R-2, & & $\mathrm{R}-3$, & & n/a & \\
\hline $\begin{array}{r}\text { CA, CO, ID, IO, ME, MI, MN, } \\
\text { MT, NH, NY, PA, SD, VT, WA, } \\
\text { WI, WY }\end{array}$ & 15 & & $(R-3)$, & & $(R-2)$, & & $\mathrm{n} / \mathbf{a}$ & & & R-1, & & $\mathrm{n} / \mathbf{a}$ & \\
\hline $\begin{array}{l}\text { CO, ID, ME, MI, MN, MT, NH, } \\
\text { NY, ND, SD, VT, WI, WY }\end{array}$ & 16 & & $(\mathrm{R}-4)$, & & $(R-2)$, & & n/a & (R-1), & & $\mathrm{R}-1$, & & $\mathrm{n} / \mathbf{a}$ & \\
\hline ME, MN & 17 & & (R-8), & & $(\mathrm{R}-6)$, & & n/a & $(\mathrm{R}-5)$ & & (R-3), & & n/a & \\
\hline $\mathrm{AK}, \mathrm{MI}, \mathrm{MN}$ & 16 & \multirow[b]{2}{*}{$7 \& 8$} & $(\mathrm{R}-4)$, & & (R-2), & & $\mathrm{n} / \mathrm{a}$ & (R-1), & & R-1, & & $\mathrm{n} / \mathrm{a}$ & \\
\hline $\begin{array}{r}\mathrm{AK}, \mathrm{CO}, \mathrm{ME}, \mathrm{MI}, \mathrm{MN}, \mathrm{ND}, \mathrm{WI}, \\
\mathrm{WY}\end{array}$ & 17 & & (R-8), & & (R-6), & & n/a & (R-5), & & $(\mathrm{R}-3)$, & & n/a & \\
\hline
\end{tabular}


Table A.4 Ceiling, Wall, and Floor Insulation R-Values for R-2, R-4, or Townhouse Residential Buildings

\begin{tabular}{|c|c|c|c|c|c|c|c|c|c|c|}
\hline \multirow[t]{3}{*}{ Table A.4.1 } & \multirow[b]{3}{*}{ Climate Zone } & \multicolumn{3}{|c|}{ Ceilings } & \multicolumn{3}{|c|}{ Walls } & \multicolumn{3}{|c|}{ Floors } \\
\hline & & \multicolumn{9}{|c|}{ Window to Wall Area Ratio } \\
\hline & & $20 \%$ & $25 \%$ & $30 \%$ & $20 \%$ & $25 \%$ & $30 \%$ & $20 \%$ & $25 \%$ & $30 \%$ \\
\hline \multirow[t]{10}{*}{2003 IECC } & 1 & $R-13$ & $\mathrm{R}-13$ & $\mathrm{R}-13$ & $R-11$ & $\mathrm{R}-11$ & $\mathrm{R}-11$ & $R-11$ & $\mathrm{R}-11$ & $\mathrm{R}-11$ \\
\hline & 2 & R-19 & R-19 & R-19 & $\mathrm{R}-11$ & R-11 & R-11 & $R-11$ & $\mathrm{R}-11$ & R-11 \\
\hline & 3 & R-19 & R-19 & R-19 & $R-11$ & R-11 & $\mathrm{R}-11$ & $\mathrm{R}-11$ & $\mathrm{R}-11$ & R-11 \\
\hline & 4 & R-19 & R-19 & R-26 & $R-11$ & R-11 & $\mathrm{R}-11$ & $\mathrm{R}-11$ & $\mathrm{R}-11$ & R-11 \\
\hline & 5 & R-19 & R-19 & R-38 & $R-11$ & R-11 & $R-13$ & $\mathrm{R}-11$ & $\mathrm{R}-11$ & R-11 \\
\hline & 6 & R-30 & $R-30$ & $R-38$ & $\mathrm{R}-13$ & $R-13$ & $R-13$ & $R-11$ & $\mathrm{R}-11$ & R-19 \\
\hline & 7 & R-30 & $R-30$ & R-38 & R-13 & $R-13$ & $R-13$ & $R-11$ & $\mathrm{R}-11$ & R-19 \\
\hline & 8 & R-30 & R-30 & R-38 & $\mathrm{R}-13$ & R-13 & R-13 & $\mathrm{R}-11$ & $\mathrm{R}-11$ & R-19 \\
\hline & 9 & R-38 & $R-30$ & R-38 & R-13 & R-13 & R-13 & $R-11$ & $\mathrm{R}-11$ & R-19 \\
\hline & 10 & R-26 & R-30 & R-38 & R-11 & R-13 & R-13 & $R-13$ & $\mathrm{R}-11$ & R-19 \\
\hline \multirow[t]{3}{*}{2006 IECC } & 1 & \multirow{3}{*}{\multicolumn{3}{|c|}{ R-30 }} & \multirow{3}{*}{\multicolumn{3}{|c|}{ R-13 }} & \multicolumn{3}{|c|}{$R-13$} \\
\hline & 2 & & & & & & & \multicolumn{3}{|c|}{$R-13$} \\
\hline & 3 & & & & & & & \multicolumn{3}{|c|}{ R-19 } \\
\hline
\end{tabular}

Difference between 2003 and 2006 IECC - Increased stringency in bold Black, decreased stringency in bold (Red), and no change in stringency is blank.

\begin{tabular}{|c|c|c|c|c|c|c|c|c|c|c|c|}
\hline States associated with climate zones & 2003 & 2006 & & Jeiling & & & Valls & & & loors & \\
\hline AS, FL, FM, GU, HI, MH, MP, PR, PW, VI & 1 & 1 & $\mathbf{R}-17$ & R-17 & $\mathbf{R}-17$ & R-2 & R-2 & R-2 & R-2 & R-2 & R-2 \\
\hline FL & 1 & \multirow{7}{*}{2} & $\mathbf{R}-17$ & $\mathbf{R}-17$ & $\mathbf{R}-17$ & R-2 & R-2 & R-2 & $\mathbf{R}-2$ & R-2 & $\mathbf{R}-2$ \\
\hline $\mathrm{FL}, \mathrm{TX}$ & 2 & & R-11 & R-11 & R-11 & R-2 & R-2 & R-2 & R-2 & R-2 & R-2 \\
\hline $\mathrm{AZ}, \mathrm{CA}, \mathrm{FL}, \mathrm{LA}, \mathrm{TX}$ & 3 & & R-11 & R-11 & R-11 & R-2 & R-2 & R-2 & R-2 & R-2 & R-2 \\
\hline $\mathrm{AL}, \mathrm{AZ}, \mathrm{FL}, \mathrm{GA}, \mathrm{LA}, \mathrm{MS}, \mathrm{TX}$ & 4 & & R-11 & R-11 & R-4 & R-2 & R-2 & R-2 & R-2 & R-2 & $\mathbf{R - 2}$ \\
\hline GA, LA, TX & 5 & & R-11 & R-11 & (R-8) & R-2 & R-2 & & R-2 & R-2 & R-2 \\
\hline GA & 6 & & & & (R-8) & & & & R-2 & R-2 & (R-6) \\
\hline GA & 7 & & & & (R-8) & & & & R-2 & R-2 & (R-6) \\
\hline $\mathrm{AZ}, \mathrm{CA}$ & 3 & \multirow{8}{*}{3} & $\mathbf{R}-11$ & R-11 & R-11 & R-2 & R-2 & R-2 & R-8 & R-8 & R-8 \\
\hline$A L, A Z, C A, M S$ & 4 & & R-11 & R-11 & R-4 & R-2 & R-2 & R-2 & $\mathbf{R}-\mathbf{8}$ & $\mathbf{R - 8}$ & $\mathbf{R}-\mathbf{8}$ \\
\hline AL, CA, GA, LA, MS, NV, SC, TX & 5 & & R-11 & R-11 & (R-8) & R-2 & R-2 & & R-8 & $\mathbf{R - 8}$ & R-8 \\
\hline $\mathrm{AL}, \mathrm{AZ}, \mathrm{AR}, \mathrm{CA}, \mathrm{GA}, \mathrm{LA}, \mathrm{MS}, \mathrm{NC}, \mathrm{OK}, \mathrm{SC}, \mathrm{TX}$ & 6 & & & & (R-8) & & & & $\mathbf{R}-\mathbf{8}$ & $\mathbf{R}-\mathbf{8}$ & \\
\hline $\mathrm{AL}, \mathrm{AZ}, \mathrm{AR}, \mathrm{GA}, \mathrm{MS}, \mathrm{NM}, \mathrm{NC}, \mathrm{OK}, \mathrm{SC}, \mathrm{TN}, \mathrm{TX}$ & 7 & & & & (R-8) & & & & R-8 & R-8 & \\
\hline AL, AR, CA, GA, NC, OK, TN & 8 & & & & (R-8) & & & & R-8 & R-8 & \\
\hline OK, TN, TX & 9 & & (R-8) & & (R-8) & & & & R-8 & R-8 & \\
\hline UT & 10 & & R-4 & & (R-8) & R-2 & & & R-6 & R-8 & \\
\hline
\end{tabular}




\begin{tabular}{|c|c|c|c|c|c|c|c|c|c|c|}
\hline \multirow[t]{3}{*}{ Table A.4.2 } & \multirow[b]{3}{*}{ Climate Zone } & \multicolumn{3}{|c|}{ Ceilings } & \multicolumn{3}{|c|}{ Walls } & \multicolumn{3}{|c|}{ Floors } \\
\hline & & \multicolumn{9}{|c|}{ Window to Wall Area Ratio } \\
\hline & & $20 \%$ & $25 \%$ & $30 \%$ & $20 \%$ & $25 \%$ & $30 \%$ & $20 \%$ & $25 \%$ & $30 \%$ \\
\hline \multirow[t]{8}{*}{2003 IECC } & 5 & $R-19$ & $R-19$ & R-38 & $\mathrm{R}-11$ & $\mathrm{R}-11$ & $R-13$ & $R-11$ & $\mathrm{R}-11$ & $R-11$ \\
\hline & 6 & $\mathrm{R}-30$ & R-30 & $R-38$ & $\mathrm{R}-13$ & $\mathrm{R}-13$ & $\mathrm{R}-13$ & $\mathrm{R}-11$ & $\mathrm{R}-11$ & R-19 \\
\hline & 7 & $\mathrm{R}-30$ & $\mathrm{R}-30$ & R-38 & $\mathrm{R}-13$ & $R-13$ & $\mathrm{R}-13$ & $\mathrm{R}-11$ & $\mathrm{R}-11$ & $\mathrm{R}-19$ \\
\hline & 8 & $\mathrm{R}-30$ & $\mathrm{R}-30$ & R-38 & $\mathrm{R}-13$ & $R-13$ & $\mathrm{R}-13$ & $\mathrm{R}-11$ & $\mathrm{R}-11$ & R-19 \\
\hline & 9 & R-38 & $\mathrm{R}-30$ & $R-38$ & $\mathrm{R}-13$ & $R-13$ & $R-13$ & $\mathrm{R}-11$ & $\mathrm{R}-11$ & R-19 \\
\hline & 10 & R-26 & $\mathrm{R}-30$ & R-38 & $\mathrm{R}-11$ & $R-13$ & $R-13$ & $\mathrm{R}-13$ & $\mathrm{R}-11$ & R-19 \\
\hline & 11 & R-26 & $\mathrm{R}-30$ & R-38 & $\mathrm{R}-13$ & $R-13$ & $R-13$ & $\mathrm{R}-11$ & $\mathrm{R}-11$ & R-19 \\
\hline & 12 & R-30 & R-30 & R-38 & $\mathrm{R}-13$ & R-13 & $R-13$ & $R-11$ & R-19 & R-19 \\
\hline \multirow[t]{2}{*}{2006 IECC } & 4 & \multirow{2}{*}{\multicolumn{3}{|c|}{$R-38$}} & \multicolumn{3}{|c|}{ R-13 } & \multicolumn{3}{|c|}{$R-19$} \\
\hline & 4 Marine & & & & \multicolumn{3}{|c|}{ R-19 } & \multicolumn{3}{|c|}{ R-30 } \\
\hline
\end{tabular}

Difference between 2003 and 2006 IECC - Increased stringency in bold Black, decreased stringency in bold (Red), and no change in stringency is blank.

\begin{tabular}{|c|c|c|c|c|c|c|c|c|c|c|}
\hline States associated with climate zones & 2003 & 2006 & \multicolumn{2}{|c|}{ Ceilings } & \multicolumn{3}{|c|}{ Walls } & \multicolumn{3}{|c|}{ Floors } \\
\hline GA & 5 & \multirow{7}{*}{4} & $\mathbf{R}-19$ & R-19 & R-2 & R-2 & & R-8 & R-8 & R-8 \\
\hline $\mathrm{GA}, \mathrm{NC}$ & 7 & & R-8 & R-8 & & & & R-8 & R-8 & \\
\hline $\mathrm{AZ}, \mathrm{AR}, \mathrm{CA}, \mathrm{GA}, \mathrm{NM}, \mathrm{NC}, \mathrm{TN}, \mathrm{TX}, \mathrm{VA}$ & 8 & & R-8 & R-8 & & & & R-8 & R-8 & \\
\hline AR, CA, DE, KA, KY, MD, MO, NM, NC, TN, TX, VA & 9 & & & $\mathbf{R}-\mathbf{8}$ & & & & R-8 & R-8 & \\
\hline $\begin{array}{r}\mathrm{AZ}, \mathrm{DE}, \mathrm{DC}, \mathrm{IL}, \mathrm{IN}, \mathrm{KA}, \mathrm{KY}, \mathrm{MD}, \mathrm{MO}, \mathrm{NJ}, \mathrm{NM}, \mathrm{NY}, \mathrm{OK}, \\
\mathrm{PA}, \mathrm{TN}, \mathrm{VA}, \mathrm{WV}\end{array}$ & 10 & & R-12 & $\mathbf{R}-\mathbf{8}$ & R-2 & & & R-6 & R-8 & \\
\hline $\begin{array}{r}\mathrm{CO}, \mathrm{IL}, \mathrm{IN}, \mathrm{KA}, \mathrm{KY}, \mathrm{MD}, \mathrm{MO}, \mathrm{NJ}, \mathrm{NM}, \mathrm{NY}, \mathrm{OH}, \mathrm{PA}, \\
\text { VA, WV }\end{array}$ & 11 & & R-12 & $\mathbf{R}-\mathbf{8}$ & & & & R-8 & R-8 & \\
\hline MD, MO, NM, NY & 12 & & R-8 & R-8 & & & & R-8 & & \\
\hline $\mathrm{CA}, \mathrm{OR}$ & 9 & & & R-8 & R-6 & R-6 & R-6 & $\mathbf{R}-19$ & R-19 & $\mathbf{R}-11$ \\
\hline OR, WA & 10 & $4-M$ & $\mathbf{R}-12$ & R-8 & R-8 & R-6 & R-6 & $\mathbf{R}-17$ & R-19 & R-11 \\
\hline OR, WA & 11 & & R-12 & R-8 & R-6 & R-6 & R-6 & R-19 & R-19 & R-11 \\
\hline WA & 12 & & R-8 & R-8 & R-6 & R-6 & R-6 & $R-19$ & $R-11$ & R-11 \\
\hline
\end{tabular}




\begin{tabular}{|c|c|c|c|c|c|c|c|c|c|c|}
\hline \multirow[t]{3}{*}{ Table A.4.3 } & \multirow[b]{3}{*}{ Climate Zone } & \multicolumn{3}{|c|}{ Ceilings } & \multicolumn{3}{|c|}{ Walls } & \multicolumn{3}{|c|}{ Floors } \\
\hline & & \multicolumn{9}{|c|}{ Window to Wall Area Ratio } \\
\hline & & $20 \%$ & $25 \%$ & $30 \%$ & $20 \%$ & $25 \%$ & $30 \%$ & $20 \%$ & $25 \%$ & $30 \%$ \\
\hline \multirow[t]{8}{*}{2003 IECC } & 10 & R-26 & $\mathrm{R}-30$ & $\mathrm{R}-38$ & $\mathrm{R}-11$ & R-13 & $\mathrm{R}-13$ & $\mathrm{R}-13$ & $\mathrm{R}-11$ & $\mathrm{R}-19$ \\
\hline & 11 & R-26 & R-30 & R-38 & R-13 & R-13 & $\mathrm{R}-13$ & $\mathrm{R}-11$ & $\mathrm{R}-11$ & $\mathrm{R}-19$ \\
\hline & 12 & R-30 & $\mathrm{R}-30$ & R-38 & $\mathrm{R}-13$ & R-13 & $\mathrm{R}-13$ & $\mathrm{R}-11$ & $\mathrm{R}-19$ & $\mathrm{R}-19$ \\
\hline & 13 & R-26 & $\mathrm{R}-30$ & R-38 & $\mathrm{R}-13$ & R-13 & $\mathrm{R}-19$ & $\mathrm{R}-19$ & $\mathrm{R}-19$ & $\mathrm{R}-19$ \\
\hline & 14 & R-30 & R-30 & R-38 & R-13 & R-13 & $\mathrm{R}-19$ & R-19 & R-19 & $\mathrm{R}-19$ \\
\hline & 15 & R-38 & $\mathrm{R}-38$ & $\mathrm{R}-49$ & R-16 & R-16 & $\mathrm{R}-21$ & $\mathrm{R}-19$ & $\mathrm{R}-19$ & $\mathrm{R}-30$ \\
\hline & 16 & R-38 & R-38 & $\mathrm{R}-49$ & R-16 & R-16 & R-21 & $\mathrm{R}-19$ & R-19 & R-30 \\
\hline & 17 & na & na & na & na & na & na & na & na & na \\
\hline \multirow[t]{3}{*}{2006 IECC } & 5 & \multicolumn{3}{|c|}{ R-38 } & \multicolumn{3}{|c|}{ R-19 } & \multirow{3}{*}{\multicolumn{3}{|c|}{ R-30 }} \\
\hline & 6 & \multirow{2}{*}{\multicolumn{3}{|c|}{$\begin{array}{l}\text { R-49 } \\
\text { R-49 }\end{array}$}} & \multicolumn{3}{|c|}{ R-19 } & & & \\
\hline & $7 \& 8$ & & & & \multicolumn{3}{|c|}{ R-21 } & & & \\
\hline
\end{tabular}

Difference between 2003 and 2006 IECC - Increased stringency in bold Black, decreased stringency in bold (Red), and no change in stringency is blank.

\begin{tabular}{|c|c|c|c|c|c|c|c|c|c|c|c|}
\hline States associated with climate zones & 2003 & 2006 & \multicolumn{3}{|c|}{ Ceilings } & \multicolumn{3}{|c|}{ Walls } & \multicolumn{3}{|c|}{ Floors } \\
\hline AZ, IL, MD, UT & 10 & \multirow{6}{*}{2000} & R-12 & $\mathbf{R}-\mathbf{8}$ & & R-8 & R-6 & R-6 & R-17 & R-19 & R-11 \\
\hline $\begin{array}{r}\mathrm{CA}, \mathrm{CO}, \mathrm{IL}, \mathrm{IN}, \mathrm{KA}, \mathrm{NJ}, \mathrm{NM}, \mathrm{NC}, \mathrm{OH}, \mathrm{PA}, \mathrm{WA}, \\
\text { WV }\end{array}$ & 11 & & R-12 & R-8 & & R-6 & R-6 & R-6 & R-19 & R-19 & R-11 \\
\hline $\begin{array}{r}\text { CT, ID, IL, IN, KA, MA, MO, NV, NJ, NM, NY } \\
\text { OH, OR, PA, RI, UT, WA, WV }\end{array}$ & 12 & & R-8 & R-8 & & R-6 & R-6 & R-6 & R-19 & R-11 & R-11 \\
\hline $\begin{array}{l}\text { AZ, CA, CO, CT, ID, IL, IN, IO, KA, MD, MA, MI, } \\
\text { MO, NB, NV, NJ, NM, NY, OH, OR, PA, UT, WV }\end{array}$ & 13 & & R-12 & R-8 & & R-6 & R-6 & & R-11 & R-11 & R-11 \\
\hline $\begin{array}{r}\text { AZ, CT, ID, IL, IN, IO, MA, MI, NB, NY, OH, OR, } \\
\text { PA, RI, SD, UT, WA, WY }\end{array}$ & 14 & & R-8 & R-8 & & R-6 & R-6 & & R-11 & R-11 & $\mathrm{R}-11$ \\
\hline $\begin{array}{r}\mathrm{CA}, \mathrm{CO}, \mathrm{ID}, \mathrm{IO}, \mathrm{MI}, \mathrm{NB}, \mathrm{NV}, \mathrm{NH}, \mathrm{NM}, \mathrm{NY}, \mathrm{OR}, \\
\mathrm{PA}, \mathrm{WA}\end{array}$ & 15 & & & & (R-11) & R-3 & R-3 & $(\mathrm{R}-2)$ & R-11 & R-11 & \\
\hline UT & 12 & & R-19 & R-19 & R-11 & R-6 & R-6 & R-6 & R-19 & R-11 & R-11 \\
\hline MI, NY & 14 & & R-19 & R-19 & R-11 & R-6 & R-6 & & R-11 & R-11 & $\mathrm{R}-11$ \\
\hline $\begin{array}{r}\mathrm{CA}, \mathrm{CO}, \mathrm{ID}, \mathrm{IO}, \mathrm{ME}, \mathrm{MI}, \mathrm{MN}, \mathrm{MT}, \mathrm{NH}, \mathrm{NY}, \mathrm{PA}, \\
\text { SD, VT, WA, WI, WY }\end{array}$ & 15 & 6 & R-11 & $\mathbf{R}-11$ & & R-3 & R-3 & (R-2) & R-11 & R-11 & \\
\hline $\begin{array}{r}\mathrm{CO}, \mathrm{ID}, \mathrm{ME}, \mathrm{MI}, \mathrm{MN}, \mathrm{MT}, \mathrm{NH}, \mathrm{NY}, \mathrm{ND}, \mathrm{SD}, \mathrm{VT} \text {, } \\
\text { WI, WY }\end{array}$ & 16 & & R-11 & R-11 & & R-3 & R-3 & (R-2) & R-11 & R-11 & \\
\hline ME, MN & 17 & & & & & & & & & & \\
\hline AK, MI, MN & 16 & 788 & R-11 & R-11 & & R-5 & R-5 & & R-11 & R-11 & \\
\hline AK, CO, ME, MI, MN, ND, WI, WY & 17 & & NA & NA & NA & NA & NA & NA & NA & NA & NA \\
\hline
\end{tabular}




\section{Appendix B: Change in Fenestration Factors}

Table B1. Fenestration U-Factors and SHGC for One- and Two-Family Dwellings

\begin{tabular}{|c|c|c|c|c|c|c|c|c|c|c|}
\hline \multirow[t]{3}{*}{ Table B.1.1 } & \multirow[t]{3}{*}{$\begin{array}{l}\text { Climate } \\
\text { Zone }\end{array}$} & \multicolumn{3}{|c|}{$\begin{array}{c}\text { Glazing U-Factor } \\
\text { (Maximum) }\end{array}$} & \multicolumn{3}{|c|}{$\begin{array}{l}\text { Skylight U-Factor } \\
\text { (Maximum) }\end{array}$} & \multicolumn{3}{|c|}{ SHGC (Minimum) } \\
\hline & & \multicolumn{9}{|c|}{ Window to Wall Area Ratio } \\
\hline & & $15 \%$ & $20 \%$ & $25 \%$ & $15 \%$ & $20 \%$ & $25 \%$ & $15 \%$ & $20 \%$ & $25 \%$ \\
\hline \multirow[t]{7}{*}{2003 IECC } & 1 & na & 0.80 & 0.70 & na & 0.80 & 0.70 & 0.40 & 0.40 & 0.40 \\
\hline & 2 & 0.90 & 0.75 & 0.50 & 0.90 & 0.75 & 0.50 & 0.40 & 0.40 & 0.40 \\
\hline & 3 & 0.75 & 0.70 & 0.55 & 0.75 & 0.70 & 0.55 & 0.40 & 0.40 & 0.40 \\
\hline & 4 & 0.75 & 0.60 & 0.52 & 0.75 & 0.60 & 0.52 & 0.40 & 0.40 & 0.40 \\
\hline & 5 & 0.65 & 0.52 & 0.50 & 0.65 & 0.52 & 0.50 & 0.40 & 0.40 & 0.40 \\
\hline & 6 & 0.60 & 0.50 & 0.46 & 0.60 & 0.50 & 0.46 & 0.40 & 0.40 & 0.40 \\
\hline & 7 & 0.55 & 0.46 & 0.45 & 0.55 & 0.46 & 0.45 & 0.40 & 0.40 & 0.40 \\
\hline \multirow[t]{2}{*}{2006 IECC } & 1 & \multirow{2}{*}{\multicolumn{3}{|c|}{$\begin{array}{l}1.20 \\
075\end{array}$}} & \multirow{2}{*}{\multicolumn{3}{|c|}{0.75}} & \multirow{2}{*}{\multicolumn{3}{|c|}{0.40}} \\
\hline & 2 & & & & & & & & & \\
\hline
\end{tabular}

Difference between 2003 and 2006 IECC - Increased stringency in bold Black, decreased stringency in bold (Red), and no change in stringency is blank.

\begin{tabular}{|c|c|c|c|c|c|c|c|c|c|}
\hline States associated with climate zones & 2003 & 2006 & Gla & $\begin{array}{l}\text { ig U-Fa } \\
\text { aximum }\end{array}$ & & $\begin{array}{r}\text { Sky } \\
\text { ( }\end{array}$ & $\begin{array}{l}\text { ht U-Fa } \\
\text { aximum }\end{array}$ & & SHGC (Minimum) \\
\hline AS, FL, FM, GU, HI, MH, MP, PR, PW, VI & 1 & 1 & na & $(0.40)$ & $(0.50)$ & na & 0.05 & $(0.05)$ & \\
\hline $\mathrm{FL}$ & 1 & & na & 0.05 & $(0.05)$ & na & 0.05 & $(0.05)$ & \\
\hline $\mathrm{FL}, \mathrm{TX}$ & 2 & & 0.15 & & $(0.25)$ & 0.15 & & $(0.25)$ & \\
\hline $\mathrm{AZ}, \mathrm{CA}, \mathrm{FL}, \mathrm{LA}, \mathrm{TX}$ & 3 & & & $(0.05)$ & $(0.20)$ & & $(0.05)$ & $(0.20)$ & \\
\hline $\mathrm{AL}, \mathrm{AZ}, \mathrm{FL}, \mathrm{GA}, \mathrm{LA}, \mathrm{MS}, \mathrm{TX}$ & 4 & 2 & & $(0.15)$ & $(0.23)$ & & $(0.15)$ & $(0.23)$ & \\
\hline GA, LA, TX & 5 & & $(0.10)$ & $(0.23)$ & $(0.25)$ & $(0.10)$ & $(0.23)$ & $(0.25)$ & \\
\hline GA & 6 & & $(0.15)$ & $(0.25)$ & $(0.29)$ & $(0.15)$ & $(0.25)$ & $(0.29)$ & \\
\hline GA & 7 & & $(0.20)$ & $(0.29)$ & $(0.30)$ & $(0.20)$ & $(0.29)$ & $(0.30)$ & \\
\hline
\end{tabular}




\begin{tabular}{|c|c|c|c|c|c|c|c|c|c|c|c|}
\hline \multirow[t]{3}{*}{ Table B.1.2 } & \multirow{3}{*}{\multicolumn{2}{|c|}{$\begin{array}{l}\text { Climate } \\
\text { Zone }\end{array}$}} & \multicolumn{3}{|c|}{$\begin{array}{l}\text { Glazing U-Factor } \\
\text { (Maximum) }\end{array}$} & \multicolumn{3}{|c|}{$\begin{array}{l}\begin{array}{l}\text { Skylight U-Factor } \\
\text { (Maximum) }\end{array} \\
\end{array}$} & \multicolumn{3}{|c|}{ SHGC (Minimum) } \\
\hline & & & \multicolumn{9}{|c|}{ Window to Wall Area Ratio } \\
\hline & & & $15 \%$ & $20 \%$ & $25 \%$ & $15 \%$ & $20 \%$ & $25 \%$ & $15 \%$ & $20 \%$ & $25 \%$ \\
\hline \multirow[t]{8}{*}{2003 IECC } & \multicolumn{2}{|c|}{3} & 0.75 & 0.70 & 0.55 & 0.75 & 0.70 & 0.55 & 0.40 & 0.40 & 0.40 \\
\hline & \multicolumn{2}{|c|}{4} & 0.75 & 0.60 & 0.52 & 0.75 & 0.60 & 0.52 & 0.40 & 0.40 & 0.40 \\
\hline & \multicolumn{2}{|c|}{5} & 0.65 & 0.52 & 0.50 & 0.65 & 0.52 & 0.50 & 0.40 & 0.40 & 0.40 \\
\hline & \multicolumn{2}{|c|}{6} & 0.60 & 0.50 & 0.46 & 0.60 & 0.50 & 0.46 & 0.40 & 0.40 & 0.40 \\
\hline & \multicolumn{2}{|c|}{7} & 0.55 & 0.46 & 0.45 & 0.55 & 0.46 & 0.45 & 0.40 & 0.40 & 0.40 \\
\hline & \multicolumn{2}{|c|}{8} & 0.50 & 0.42 & 0.41 & 0.50 & 0.42 & 0.41 & $\mathrm{NR}$ & $\mathrm{NR}$ & NR \\
\hline & \multicolumn{2}{|c|}{9} & 0.45 & 0.37 & 0.37 & 0.45 & 0.37 & 0.37 & NR & NR & NR \\
\hline & \multicolumn{2}{|c|}{10} & 0.45 & 0.37 & 0.33 & 0.45 & 0.37 & 0.33 & NR & NR & NR \\
\hline 2006 IECC & \multicolumn{2}{|c|}{3} & \multicolumn{3}{|c|}{0.65} & \multicolumn{3}{|c|}{0.65} & \multicolumn{3}{|c|}{0.40} \\
\hline \multicolumn{12}{|c|}{$\begin{array}{l}\text { Difference between } 2003 \text { and } 2006 \text { IECC - Increased stringency in bold Black, decreased stringency in bold (Red), and } \\
\text { no change in stringency is blank. }\end{array}$} \\
\hline States associated with climate zones & 2003 & 2006 & \multicolumn{3}{|c|}{$\begin{array}{c}\text { Glazing U-Factor } \\
\text { (Maximum) }\end{array}$} & \multicolumn{3}{|c|}{$\begin{array}{l}\text { Skylight U-Factor } \\
\text { (Maximum) }\end{array}$} & \multicolumn{3}{|c|}{ SHGC (Minimum) } \\
\hline $\mathrm{AZ}, \mathrm{CA}$ & 3 & \multirow{8}{*}{3} & 0.10 & 0.05 & $(0.10)$ & 0.10 & 0.05 & $(0.10)$ & & & \\
\hline $\mathrm{AL}, \mathrm{AZ}, \mathrm{CA}, \mathrm{MS}$ & 4 & & 0.10 & $(0.05)$ & $(0.13)$ & 0.10 & $(0.05)$ & $(0.13)$ & & & \\
\hline AL, CA, GA, LA, MS, NV, SC, TX & 5 & & & $(0.13)$ & $(0.15)$ & & $(0.13)$ & $(0.15)$ & & & \\
\hline AL, AZ, AR, CA, GA, LA, MS, NC, OK, SC, & 6 & & $(0.05)$ & $(0.15)$ & $(0.19)$ & $(0.05)$ & $(0.15)$ & $(0.19)$ & & & \\
\hline $\begin{array}{r}\mathrm{AL}, \mathrm{AZ}, \mathrm{AR}, \mathrm{GA}, \mathrm{MS}, \mathrm{NM}, \mathrm{NC}, \mathrm{OK}, \mathrm{SC}, \mathrm{TN}, \\
\mathrm{TX}\end{array}$ & 7 & & $(0.10)$ & $(0.19)$ & $(0.20)$ & $(0.10)$ & $(0.19)$ & $(0.20)$ & & & \\
\hline AL, AR, CA, GA, NC, OK, TN & 8 & & $(0.15)$ & $(0.23)$ & $(0.24)$ & $(0.15)$ & $(0.23)$ & $(0.24)$ & 0.40 & 0.40 & 0.40 \\
\hline OK, TN, TX & 9 & & $(0.20)$ & $(0.28)$ & $(0.28)$ & $(0.20)$ & $(0.28)$ & $(0.28)$ & 0.40 & 0.40 & 0.40 \\
\hline UT & 10 & & $(0.20)$ & $(0.28)$ & $(0.32)$ & $(0.20)$ & $(0.28)$ & $(0.32)$ & 0.40 & 0.40 & 0.40 \\
\hline
\end{tabular}




\begin{tabular}{|c|c|c|c|c|c|c|c|c|c|c|c|}
\hline \multirow[t]{2}{*}{ Table B.1.3 } & \multirow{2}{*}{\multicolumn{2}{|c|}{$\begin{array}{l}\text { Climate } \\
\text { Zone }\end{array}$}} & \multicolumn{3}{|c|}{$\begin{array}{l}\text { Glazing U-Factor } \\
\text { (Maximum) }\end{array}$} & \multicolumn{3}{|c|}{$\begin{array}{l}\text { Skylight U-Factor } \\
\text { (Maximum) }\end{array}$} & \multicolumn{3}{|c|}{ SHGC (Minimum) } \\
\hline & & & $15 \%$ & $20 \%$ & $25 \%$ & $15 \%$ & $20 \%$ & $25 \%$ & $15 \%$ & $20 \%$ & $25 \%$ \\
\hline \multirow{4}{*}{2003 IECC } & \multicolumn{2}{|c|}{7} & 0.55 & 0.46 & 0.45 & 0.55 & 0.46 & 0.45 & 0.40 & 0.40 & 0.40 \\
\hline & \multicolumn{2}{|c|}{8} & 0.50 & 0.42 & 0.41 & 0.50 & 0.42 & 0.41 & NR & NR & NR \\
\hline & \multicolumn{2}{|c|}{9} & 0.45 & 0.37 & 0.37 & 0.45 & 0.37 & 0.37 & NR & NR & NR \\
\hline & \multicolumn{2}{|c|}{12} & 0.40 & 0.33 & 0.27 & 0.40 & 0.33 & 0.27 & NR & NR & NR \\
\hline \multirow[t]{2}{*}{2006 IECC } & \multirow{2}{*}{\multicolumn{2}{|c|}{4 Marine }} & \multirow{2}{*}{\multicolumn{3}{|c|}{0.40}} & \multirow{2}{*}{\multicolumn{3}{|c|}{0.60}} & \multirow{2}{*}{\multicolumn{3}{|c|}{ NR }} \\
\hline & & & & & & & & & & & \\
\hline \multicolumn{12}{|c|}{$\begin{array}{l}\text { Difference between } 2003 \text { and } 2006 \text { IECC - Increased stringency in bold Black, decreased stringency in bold (Red), and } \\
\text { no change in stringency is blank. }\end{array}$} \\
\hline AZ, AR, CA, GA, NM, NC, TN, TX, VA & 8 & \multirow{5}{*}{4} & 0.10 & 0.02 & 0.01 & $(0.10)$ & $(0.18)$ & $(0.19)$ & & & \\
\hline $\begin{array}{r}\text { AR, CA, DE, KA, KY, MD, MO, NM, NC, TN, } \\
\text { TX, VA }\end{array}$ & 9 & & 0.05 & $(0.03)$ & $(0.03)$ & $(0.15)$ & $(0.23)$ & $(0.23)$ & & & \\
\hline $\begin{array}{r}A Z, D E, D C, I L, I N, K A, K Y, M D, M O, N J, N M, \\
\text { NY, OK, PA, TN, VA, WV }\end{array}$ & 10 & & 0.05 & $(0.03)$ & $(0.07)$ & $(0.15)$ & $(0.23)$ & $(0.27)$ & & & \\
\hline $\begin{array}{r}\mathrm{CO}, \mathrm{IL}, \mathrm{IN}, \mathrm{KA}, \mathrm{KY}, \mathrm{MD}, \mathrm{MO}, \mathrm{NJ}, \mathrm{NM}, \mathrm{NY} \\
\mathrm{OH}, \mathrm{PA}, \mathrm{VA}, \mathrm{WV}\end{array}$ & 11 & & 0.05 & $(0.04)$ & $(0.11)$ & $(0.15)$ & $(0.24)$ & $(0.31)$ & & & \\
\hline MD, MO, NM, NY & 12 & & & $(0.07)$ & $(0.13)$ & $(0.20)$ & $(0.27)$ & $(0.33)$ & & & \\
\hline CA, OR & 9 & \multirow{4}{*}{$4 \mathrm{M}$} & 010 & 002 & 00 ?0 & $(0,15)$ & (0 23) & $(023)$ & & & \\
\hline OR, WA & 10 & & 0.10 & 0.02 & $(0.02)$ & $(0.15)$ & $(0.23)$ & $(0.27)$ & & & \\
\hline OR, WA & 11 & & 0.10 & 0.01 & $(0.06)$ & $(0.15)$ & $(0.24)$ & $(0.31)$ & & & \\
\hline WA & 12 & & 0.05 & $(0.02)$ & $(0.08)$ & $(0.20)$ & $(0.27)$ & $(0.33)$ & & & \\
\hline
\end{tabular}




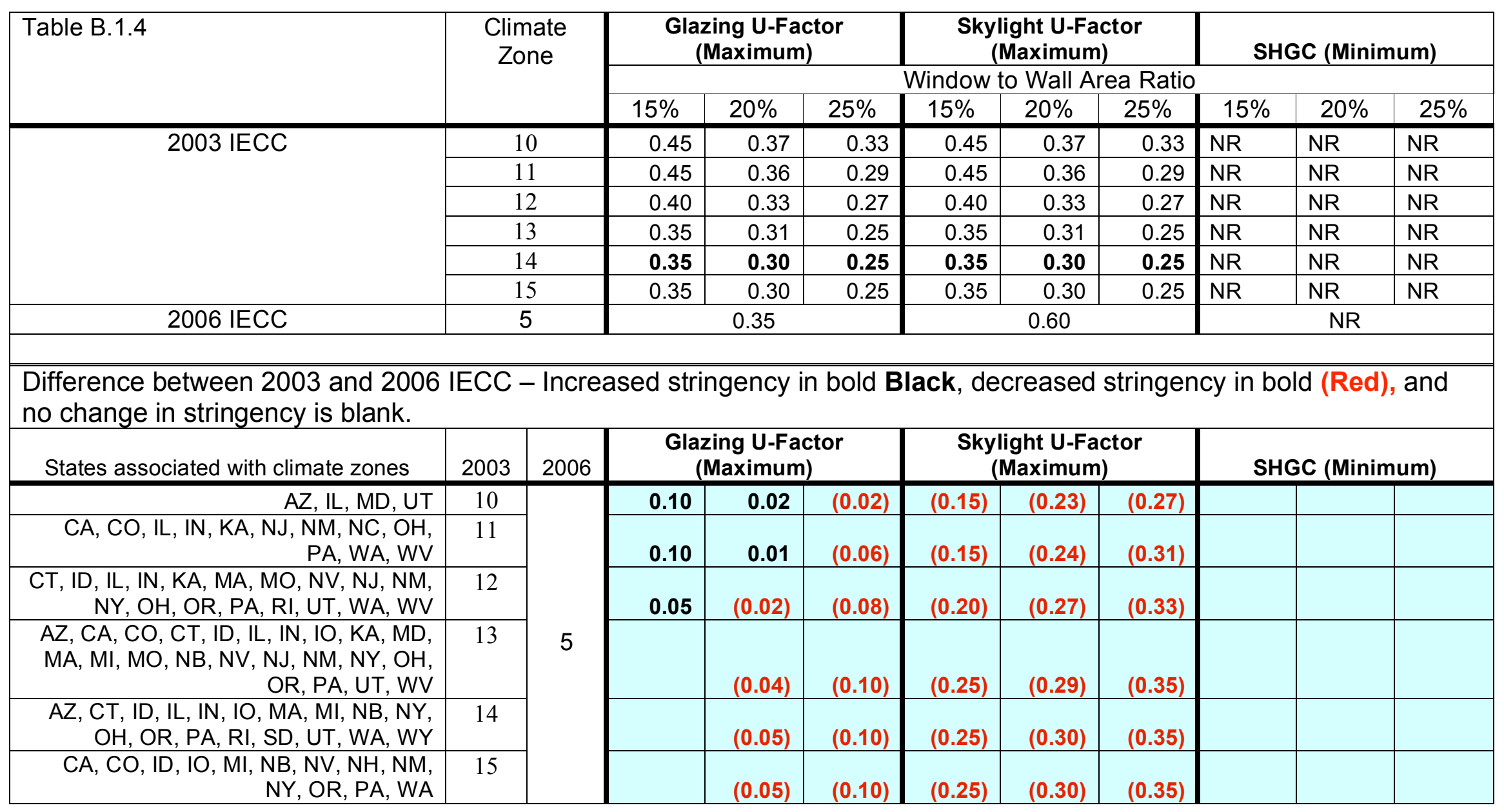




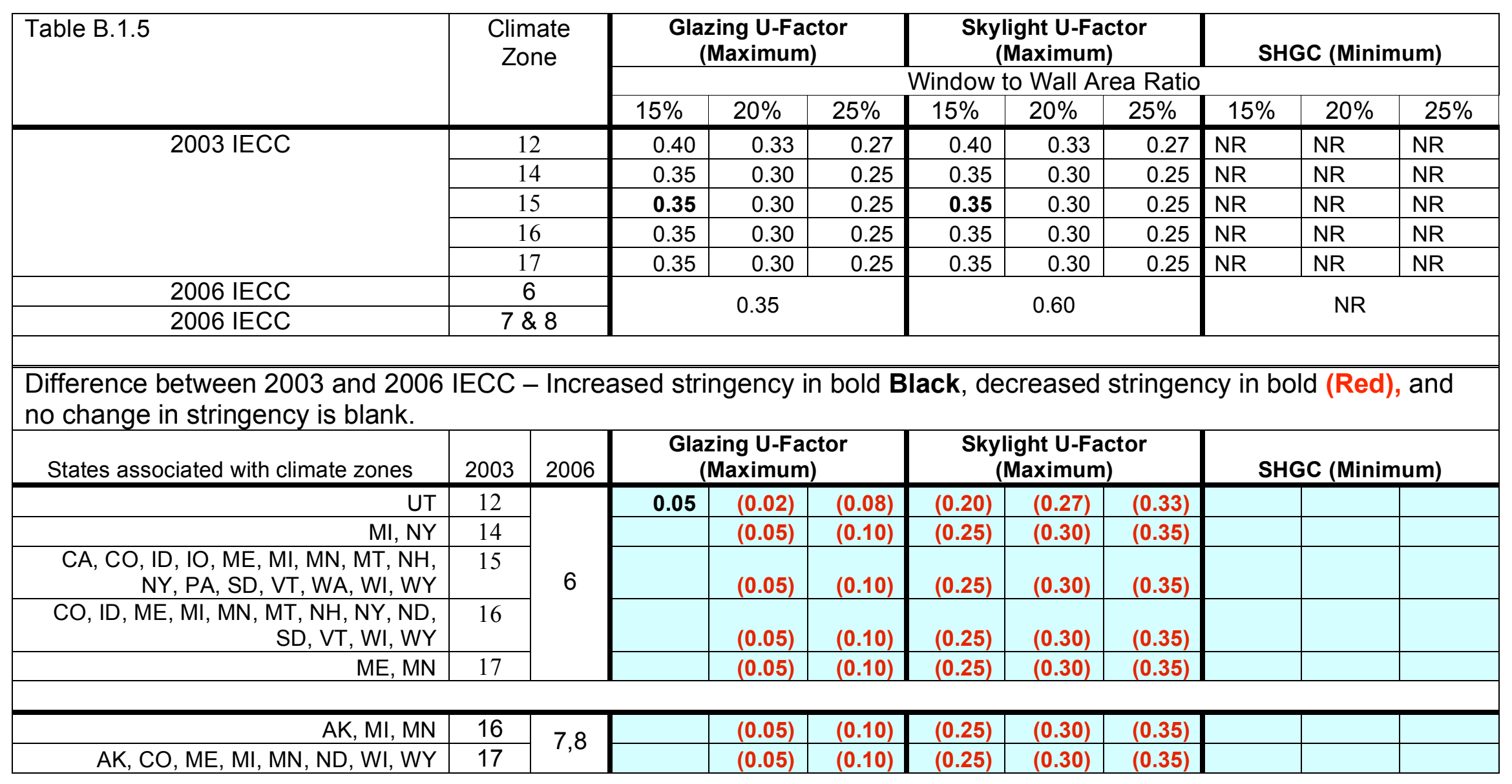


ORNL/TM-2007/043

\section{Internal Distribution}

T. K. Stovall

V. D. Baxter

W. G. Craddick

A. O. Desjarlais

P. Hughes

J. S. Kelley

ORNL Office of Technical Information and Classification

\section{External Distribution}

Jean Boulin, Department of Energy, N61, 1000 Independence Avenue SW, Forrestal Building G-050, Washington, DC 20585

James Rannels, U.S. Department of Energy, N61, 1000 Independence Avenue SW, Forrestal Building G050, Washington, DC 20585 